University of South Florida

DIGITAL COMMONS

Digital Commons @ University of

@ UNIVERSITY OF SOUTH FLORIDA

South Florida

$1-1-2014$

\title{
2014 Accountability Report USF System
}

USF

Follow this and additional works at: https://digitalcommons.usf.edu/usf_accountability_reports

\section{Scholar Commons Citation}

USF, "2014 Accountability Report USF System" (2014). USF Accountability Reports. 43.

https://digitalcommons.usf.edu/usf_accountability_reports/43

This Article is brought to you for free and open access by the USF Archives at Digital Commons @ University of South Florida. It has been accepted for inclusion in USF Accountability Reports by an authorized administrator of Digital Commons @ University of South Florida. For more information, please contact digitalcommons@usf.edu. 


\section{3-14 \\ Annual Accountability Report}

\section{UNIVERSITY OF SOUTH FLORIDA SYSTEM}

STATE UNIVERSITY SYSTEM of FLORIDA Board of Governors 


\section{TABLE OF CONTENTS}

\section{EXECUTIVE SUMMARY}

DASHBOARD

p. 2

KEY ACHIEVEMENTS

p. 5

NARRATIVE

p. 6

\section{DATA TABLES}

SECTION 1. FINANCIAL RESOURCES p. 13

SECTION 2. PERSONNEL p. 17

SECTION 3. ENROLLMENT p. 18

SECTION 4. UNDERGRADUATE EDUCATION p. 22

SECTION 5. GRADUATE EDUCATION p. 31

SECTION 6. RESEARCH \& ECONOMIC DEVELOPMENT p. 34 


\section{Dashboard}

\begin{tabular}{|c|c|c|c|c|c|c|c|c|}
\hline $\begin{array}{l}\text { Headcount } \\
\text { Enrollments }\end{array}$ & $\begin{array}{l}\text { Fall } \\
2013\end{array}$ & $\begin{array}{c}\% \\
\text { Total }\end{array}$ & $\begin{array}{l}2012-2013 \\
\% \text { Change }\end{array}$ & \multicolumn{3}{|c|}{ Degree Programs Offered } & \multicolumn{2}{|c|}{2012 Carnegie Classifications } \\
\hline TOTAL & 48,315 & $100 \%$ & $1 \%$ & \multicolumn{2}{|c|}{ TOTAL (as of Spring 2014) } & 302 & \multirow{2}{*}{ Basic: } & \multirow{10}{*}{$\begin{array}{l}\text { The USF System is } \\
\text { not classified by the } \\
\text { Carnegie Foundation. } \\
\text { The individual } \\
\text { campus reports } \\
\text { provide these } \\
\text { classifications. }\end{array}$} \\
\hline White & 27,564 & $57 \%$ & $-3 \%$ & Baccalaureate & & 129 & & \\
\hline Hispanic & 8,063 & $17 \%$ & $5 \%$ & Master's & & 127 & \multirow{2}{*}{$\begin{array}{l}\text { Undergraduate } \\
\text { Instructional Program: }\end{array}$} & \\
\hline Black & 4,789 & $10 \%$ & $-2 \%$ & Research Doctorate & & 42 & & \\
\hline Other & 7,899 & $16 \%$ & $13 \%$ & Professional Doctor & & 4 & \multirow{2}{*}{$\begin{array}{l}\text { Graduate Instructional } \\
\text { Program: }\end{array}$} & \\
\hline Full-Time & 32,469 & $67 \%$ & $1 \%$ & \multirow{2}{*}{$\begin{array}{c}\text { Faculty } \\
\text { (Fall 2013) }\end{array}$} & \multirow{2}{*}{$\begin{array}{l}\text { Full- } \\
\text { Time }\end{array}$} & \multirow{2}{*}{$\begin{array}{l}\text { Part- } \\
\text { Time }\end{array}$} & & \\
\hline Part-Time & 15,846 & $33 \%$ & $2 \%$ & & & & \multirow{2}{*}{ Size and Setting: } & \\
\hline Undergraduate & 36,012 & $75 \%$ & $0 \%$ & TOTAL & 2,047 & 820 & & \\
\hline Graduate & 10,320 & $21 \%$ & $6 \%$ & Tenure \& Ten. Track & 1,125 & 39 & \multirow{2}{*}{$\begin{array}{l}\text { Community } \\
\text { Engagement: }\end{array}$} & \\
\hline Unclassified & 1,983 & $4 \%$ & $0 \%$ & Non-Tenured Faculty & 922 & 781 & & \\
\hline
\end{tabular}

\section{DEGREE PRODUCTIVTYY AND PROGRAM EFFICIENCY}
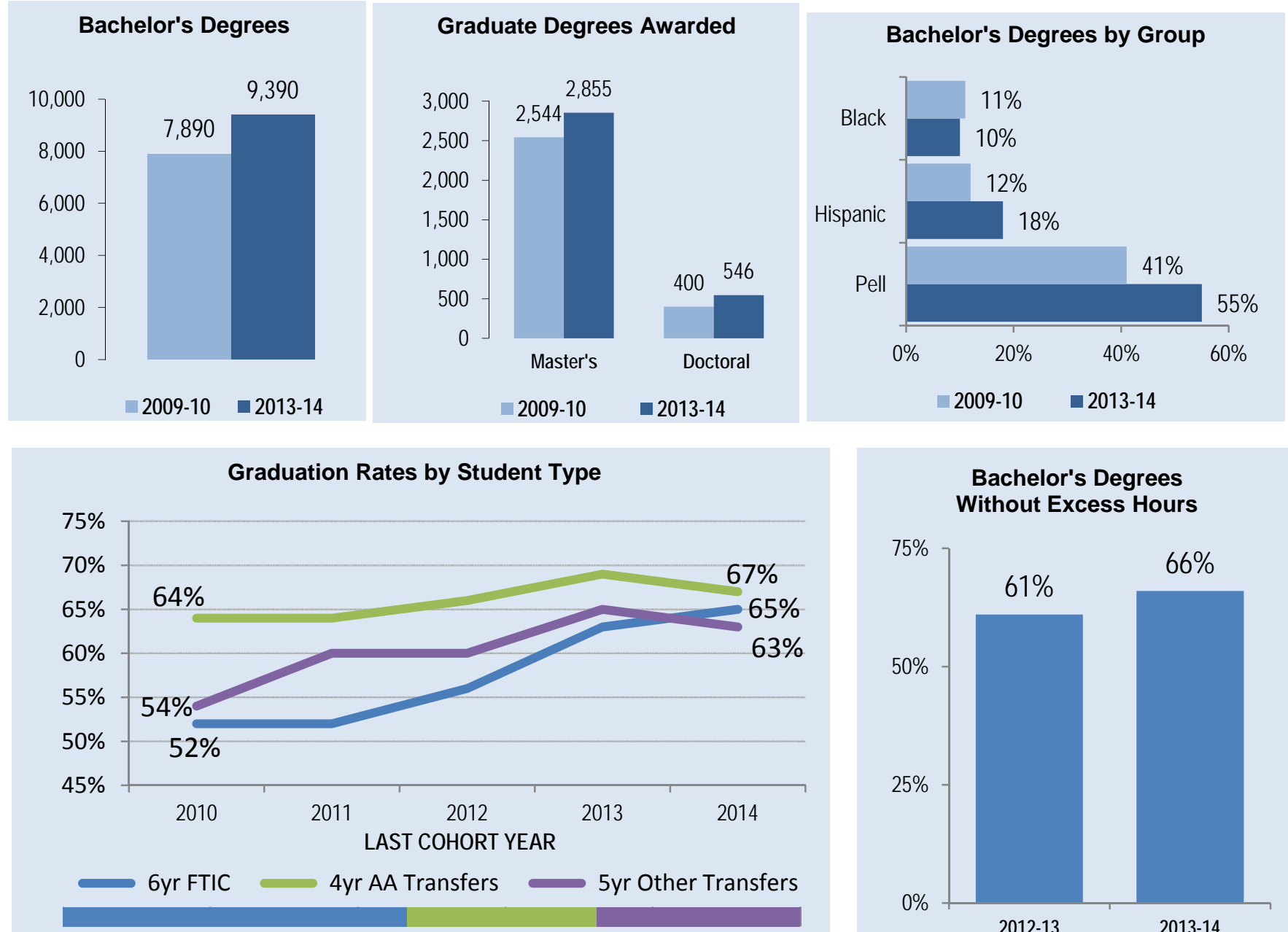

COHORT SIZES FOR COHORTS ENDING IN 2014

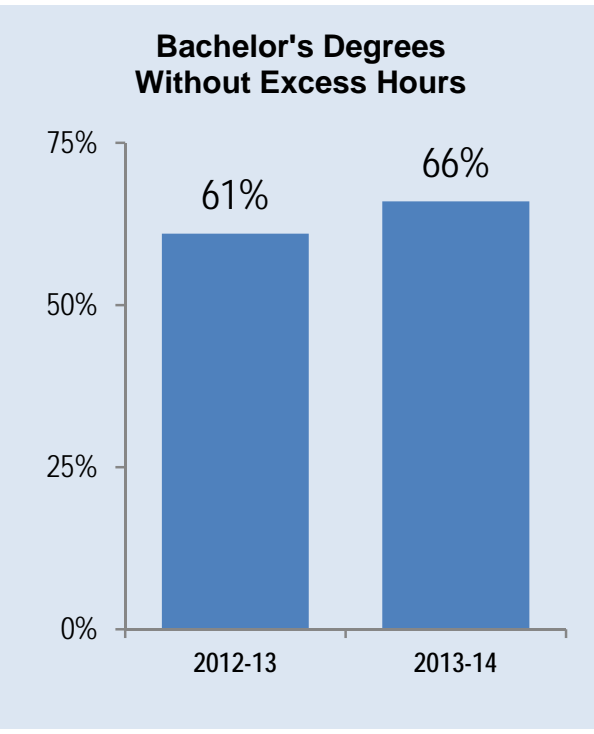

Note*: 2014 graduation rates are preliminary. 


\section{Dashboard}

\section{DEGREES AWARDED IN PROGRAMS OF STRATEGIC EMPHASS}
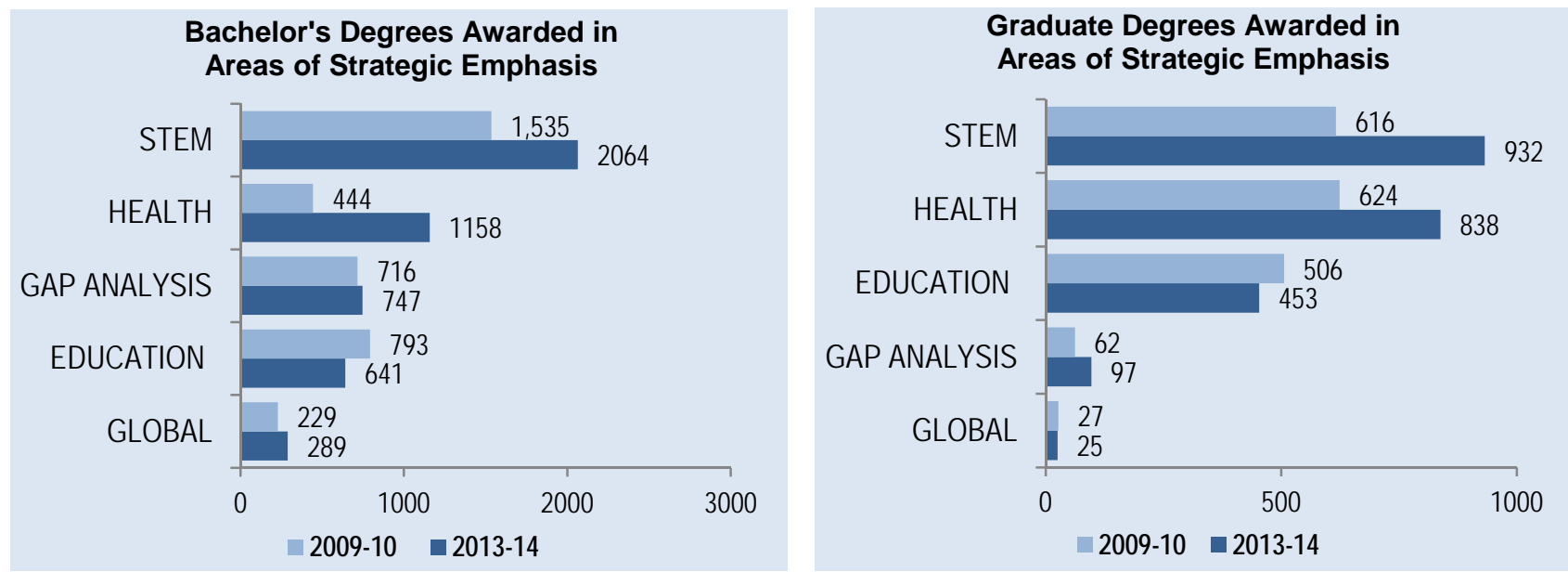

Note: The Programs of Strategic Emphasis were revised by the Board of Governors (11/2013), these graphs report the new categories.

\section{RESEARCH AND COMMERCIALIZATION ACTIMTY}
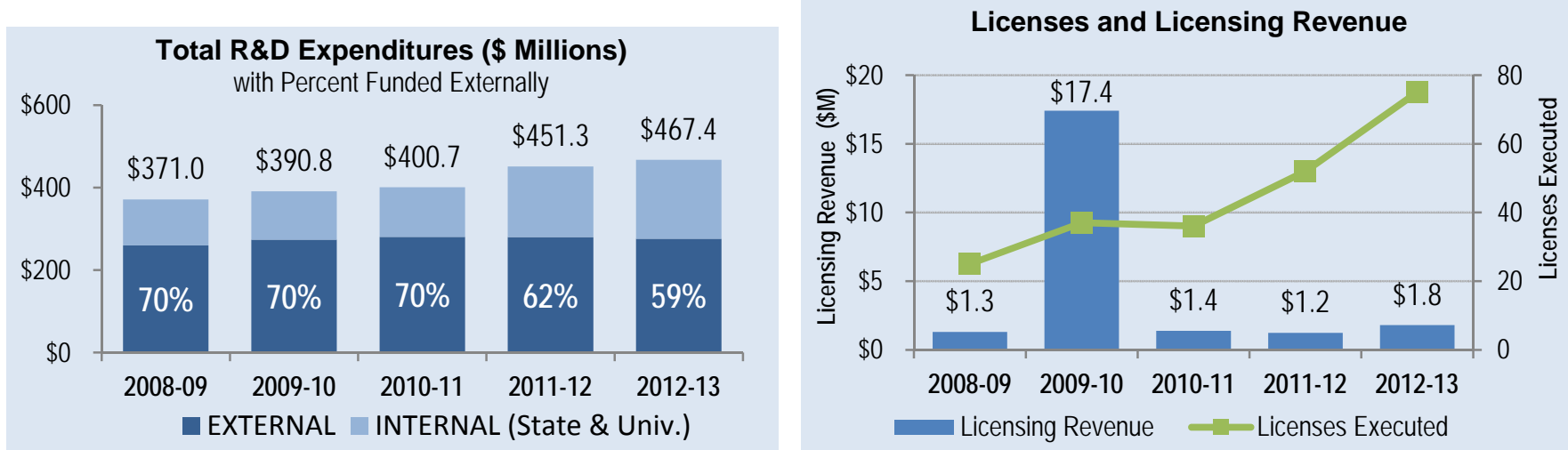

\section{RESOURCES}

\begin{tabular}{|c|c|c|c|c|c|}
\hline \multicolumn{6}{|c|}{ Appropriated Funding Per Actual US FTE } \\
\hline$\$ 15,000$ & $\$ 11,309$ & $\$ 11,956$ & $\$ 11,467$ & & $\$ 13,096$ \\
\hline$\$ 10,000$ & & & & & \\
\hline$\$ 5,000$ & $65 \%$ & $66 \%$ & $500 \%$ & & $510 \%$ \\
\hline \multirow{2}{*}{$\$ 0$} & & & & & \\
\hline & 2009-10 & 2010-11 & 2011-12 & $2012-13$ & 2013-14 \\
\hline TOTAL & $\$ 11,309$ & $\$ 11,956$ & $\$ 11,467$ & $\$ 10,164$ & $\$ 13,096$ \\
\hline - TUITION & $\$ 3,954$ & $\$ 4,113$ & $\$ 4,698$ & $\$ 5,169$ & $\$ 6,028$ \\
\hline — STATE & $\$ 7,355$ & $\$ 7,843$ & $\$ 6,769$ & $\$ 4,995$ & $\$ 7,068$ \\
\hline
\end{tabular}

Note: Tuition is the appropriated budget authority, not the amount actually collected. This tuition data includes state supported financial aid and does not include noninstructional local fees. State includes General Revenues, Lottery and Other Trust funds (i.e., Federal Stimulus for 2010-11 and 2011-12 only). Student FTE are actual (not funded) and based on the national definition. 


\section{Dashboard}

\section{POST-GRADUATION METRICS}

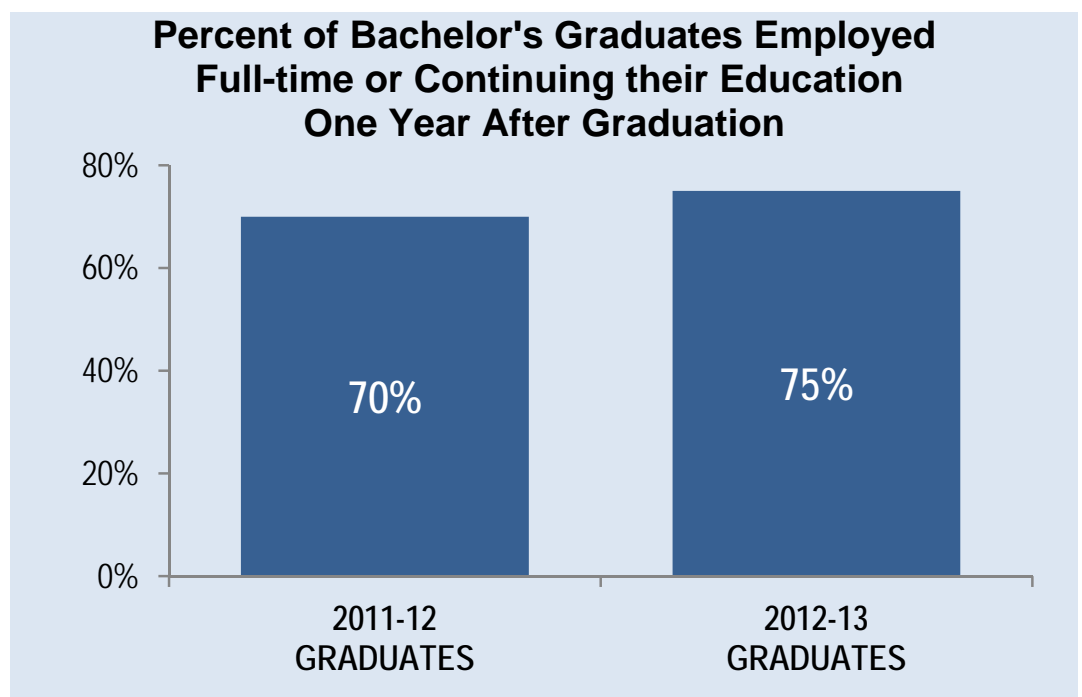

Notes: Percentages are based on the number of recent baccalaureate graduates who are either employed full-time or continuing their education in the U.S. Full-time employment is based on those who earned more than a fulltime (40hrs a week) worker making minimum wage. Due to limitations in the data, the continuing enrollment data includes any enrollment the following year regardless of whether the enrollment was post-baccalaureate or not. These data account for $87 \%$ and $90 \%$ of the total graduating class for 2011-12 and 2012-13, respectively.

For more details see table 40 within this report.

\section{Wages of Full-time Employed in Florida Baccalaureates One Year After Graduation 25th, 50th and 75th Percentiles}

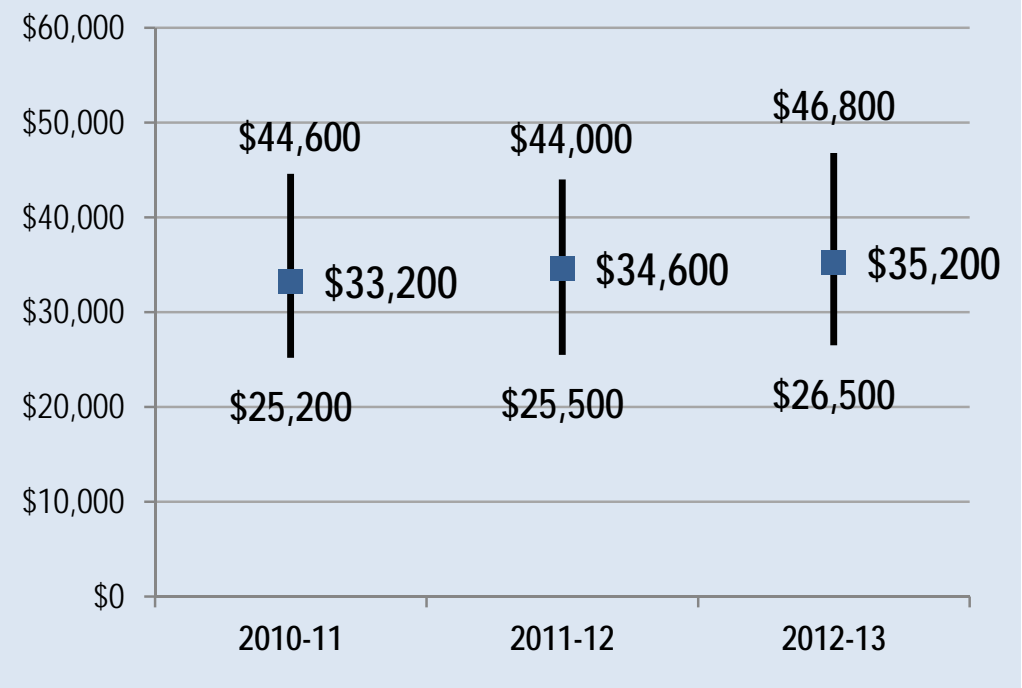

Notes: Wage data is based on Florida's annualized Unemployment Insurance (UI) wage data for those graduates who earned more than a full-time employee making minimum wage in the fiscal quarter a full year after graduation. This wage data excludes graduates who were enrolled, regardless of their earnings. This UI wage data does not include individuals who are self-employed, employed out of state, employed by the military or federal government, or those without a valid social security number. These data account for $53 \%, 51 \%$ and $53 \%$ of the total graduating class for 2010-11, 2011-12 and 2012-13, respectively. Wages rounded to nearest hundreds. 


\section{Key Achievements (2013-2014)}

STUDENT AWARDS/ACHIEVEMENTS

1. Among the dozens of nationally competitive awards across the USF System, three USF students earned a Goldwater Scholarship Award, the most prestigious undergraduate award for science and research. Michael Calzadilla, Kaitlin Deutsch and Fiona Kearns are Florida's only 2013 Goldwater Scholars.

2. At USF St. Petersburg, two undergraduate Graphic Design students (S. Schneider and J. Foster) won $1^{\text {st }}$ and $2^{\text {nd }}$ place for their work from the Clearwater/Tampa Bay Chapter of the National Society of Arts and Letters.

3. USF Sarasota-Manatee student Eric Geimer, majoring in Interdisciplinary Social Sciences, published the paper "The Efficacy of Mathematics Education" in the Science, Technology, Engineering, Art, and Mathematics Journal.

\section{FACULTY AWARDSI ACHIEVEMENTS}

1. Six USF faculty members were named Fellows of the American Association of for the Advancement of Science - putting USF in the top 10 organizations worldwide for AAAS Fellows.

2. Dr. M. Durand, USFSP professor of psychology, was awarded the 2014 Princeton Lecture Series Fellowship in recognition of his contributions to the diagnosis and treatment of autism.

3. Dr. Cihan Cobanoglu, Dean of the USF Sarasota-Manatee College of Hospitality \& Technology Leadership, was selected as recipient of the 2014 Bradenton Area Convention and Visitor's Bureau's 2014 Tourism Catalyst Award.

\section{PROGRAMAWARDS/ACHIEVEMENTS}

1. USF's graduate entrepreneurship program was ranked 13 nationally by Entrepreneur magazine and the Princeton Review. It is the only Florida school that made the list.

2. US News and World Report ranked USFSP's online MBA program in the top 100 for 2014.

3. USF Sarasota-Manatee's College of Education received the Innovation in Teacher Education Award from the Southern Regional Association of Teacher Educators (SRATE).

\section{RESEARCH AWARDS/ACHIEVEMENTS}

1. USF moved up 10 spots in national research rankings, now No. 43 in the National Science Foundation's rankings of public and private institutions' total research spending nationwide (\#27 among public universities).

2. USF ranked No. 12 in the world for U.S. utility patents with 95 patents in 2013.

3. USFSP received $\$ 1 \mathrm{M}$ SunSense grant from Duke Energy to install solar panels on the parking garage and to research solar energy generation and storage.

\section{INSTITUTIONAL AWARDS/ACHIEVEMENTS}

1. For the second year in a row, USF was a leader in the Board of Governors' performance-based funding model, coming in at No. 2 in 2013-14 in key measures of student success.

2. USF had its best fundraising year yet in 2013 , with a record-setting $\$ 113$ million raised in a single year for the USF Unstoppable campaign. The campaign has raised more than $\$ 800$ million toward its $\$ 1$ billion goal.

3. The USF Sarasota-Manatee College of Business earned accreditation from the Association to Advance Collegiate Schools of Business (AACSB). 


\section{Narrative}

\section{Teaching and Learning}

STRENGTHEN QUALTTY AND REPUTATION OF ACADEMIC PROGRAMS AND UNIVERSTIIES

Across the USF System, we work through a spirit of collaboration to provide a wide array of high-quality education options to students across the Tampa Bay region. The distinctive identities of each of our institutions - USF, USF St. Petersburg, and USF Sarasota-Manatee - help to build our collective strength, and our myriad shared services help maximize efficiencies.

In Tampa, USF celebrated its strongest freshman class ever, the Class of 2017, with an average GPA of 4.0 and SAT score of 1200. Another high point: having three Goldwater Scholars, the only recipients of the coveted undergraduate science award in the State University System.

In St. Petersburg, the online MBA program was recognized among the top 100 online MBA programs in US News and World Report. Moreover, in a recent ranking in Financial Engineer, the USFSP MBA program was fifth in Florida among the MBA programs offered both at private and public universities.

USF Sarasota-Manatee achieved specialized accreditation from the Association to Advance Collegiate Schools of Business (AACSB) and met the preconditions for accreditation from the National Council for Accreditation of Teacher Education (NCATE). USF Sarasota-Manatee's undergraduate degree in Hospitality is well on its way for specialized accreditation under the Accreditation Commission for Programs in Hospitality Administration (ACPHA).

\section{INCREASE DEGREE PRODUCTIVTYY AND PROGRAM EFFICIENCY}

Degree productivity and program efficiency comes from a commitment to student success. Across the System, the student success movement has grown from a good idea to transformative culture. Our students are performing better than ever before, and they're moving toward graduation and jobs in a timely, productive fashion.

During the 2013-14 academic year, USF in Tampa again broke institutional records with a 63 percent graduation rate. The first- to second-year retention rate is another point of pride for USF at nearly 90 percent. To further improve this metric, USF developed new first-year programs to help students transition from high school to college life. These include new academic foundations curriculum offerings, a common reading experience, and a freshman summer institute (U-First) that provides personal support for first-year students - many of whom are the first in their families to go to college.

Similarly, USFSP has been working extremely hard to improve retention rates by improving the studentlife experience: building new living-and-learning communities, placing a heavy emphasis on student involvement in organizations and campus events, and also offering a university success course. 
USF Sarasota-Manatee is similarly focused on timely degree completion and retention, particularly as it works to increase its lower-level offerings, which provide a greatly needed service to area transfer students.

Across the System, each institution is also expanding alternative course deliveries, including online learning, to best meet students' needs. A quarter of our FTE enrollment in 2013-14 was offered via alternative methods of instruction. Students can now complete all of their general education courses online.

Each member of the USF community deserves credit for these efforts. When we set about making student success the centerpiece of our mission, we did so by making it the responsibility of every person and unit on our campuses and by sharing services and best practices to ensure maximized efficiencies. We set expectations high, and the USF System continues to rise to the challenge.

\section{INCREASE THE NUMBER OF DEGREES AWARDED IN S.T.E.M AND OTHER PROGRAMS OF STRATEGIC EMPHASIS}

In 2013-14, 51 percent of the USF System's undergraduate degrees were awarded in areas of strategic emphasis, including 21 percent in STEM; In graduate degrees, 69 percent of our degrees were in areas of strategic emphasis, including 27 percent in STEM. This reflects our focus on preparing our students for the high-demand jobs of the future.

These jobs include cybersecurity - the subject of one of USF's newest master's degrees under the umbrella of the statewide Florida Center for Cybersecurity. USF's new M.S. in cybersecurity, which includes four concentrations, attracted a strong first cohort of nearly 40 students for its launch in fall 2014, with a similarly sized cohort expected for spring of 2015.

Additionally, we had a record number of M.D. graduates in 2013-14, with 125 talented new doctors now entering the healthcare workforce across Florida and the nation.

At USFSP, biology is now the most popular major on campus - even though it is only a few years old. There are now 650 biology majors and 150 majors in health science, a reflection of the growing demand across the community for more science-based educational options.

USF Sarasota-Manatee was also approved to offer a bachelor's degree in biology, beginning in the fall of 2014. Faculty designed the degree program for students interested in preparing for graduate school, as well as those seeking careers in the health professions (e.g., MD, DDS, DVM). 


\section{Narrative}

\section{Scholarship, Research and Innovation \\ STRENGTHEN QUALTYY AND REPUTATION OF SCHOLARSHIP, RESEARCH AND INNOVATION}

USF System research continues to make a major impact on Florida in the study of brain research, aging, heart health, infectious disease, drug discovery, robotics, biometrics, big data, cybersecurity, climate change, coastal biology and ecosystems, among others.

One of 40 public research universities nationwide designated as both "very high research activity" and "community engaged" by the Carnegie Foundation for the Advancement of Teaching, USF is classified in the top tier of research universities, a distinction attained by only 2.3 percent of all universities. USF moved up this year to $43^{\text {rd }}$ in the nation for total research expenditures among all U.S. universities, public or private (\#27 among all public universities), and $2^{\text {nd }}$ in Florida, and was awarded a record $\$ 467 \mathrm{M}$ in research contracts and grants, an increase of nearly \$15M. During 2013-2014, USF faculty were recognized with $70 \mathrm{AAU}, \mathrm{TARU}, \mathrm{NRC}$ and other highly prestigious awards, including two Sloan research fellowships, four NSF CAREER awards, six AAAS Fellows, two Core Fulbrights, a AAAS-Lemelson Invention Ambassador and the Rome prize.

At USF St. Petersburg, faculty reputation and productivity continues to grow. For example, more than 60 percent of tenured or tenure-track faculty in English have published a book over the last three years, significantly outperforming English faculty at other SUS institutions in terms of the percentage of faculty with books. Additionally, in 2013-2014, Fulbright grants were awarded to three USFSP faculty. Meanwhile, USFSP faculty continue to engage with both undergraduate and graduate students in research projects, publishing peer-reviewed journal articles and conducting other projects that expose students to meaningful problem-solving and inquiry skills.

USF Sarasota-Manatee is focusing efforts to strengthen the quality and reputation of scholarship, research, and innovation through meaningful community relationships. In October 2013 USF SarasotaManatee announced a gift of \$2,000,000 from the McKibbon Foundation to establish the M3 Center for Hospitality Technology and Innovation. This funding elevates the former McKibbon Hotel Management Professorship to the McKibbon Hotel Management Endowed Chair, funds graduate assistants within the College of Hospitality and Technology Leadership, and underwrites student and faculty participation in national and international conferences.

\section{INCREASE RESEARCH AND COMMERCIALIZATION ACTIMTY}

USF has cultivated a spirit of entrepreneurship and innovation across the System, aggressively pursuing grants and contracts, promoting interdisciplinary collaboration and working hard to bring scientific discoveries to the market.

As federal funding has waned, USF has proactively worked to increase funding through private partnerships (3.9 percent increase from last year) and state and local government (13.1 percent 
increase) and to increase both grant proposals submitted by USF researchers (8 percent increase from last year) and dollars requested (14.3 percent increase) - a strategy that led to record-breaking award dollars in 2013-14.

A global leader in patenting, USF ranks $12^{\text {th }}$ among universities worldwide receiving U.S. utility patents (IPO/NAI 2013) and has ranked in the top 15 for the past 4 years. 2013-14 was also a record-breaking year for USF commercialization activities, with 91 licenses and option agreements negotiated (21 percent increase from the previous year), 113 U.S. patents issued (49 percent increase) and 11 start-up companies created (12 percent increase).

The USF Tampa Bay Technology Incubator (TBTI) grew from 42 to 55 resident and affiliate companies in 2013-14. TBTI companies have created and retained 193 jobs with salaries averaging $\$ 70,000$. Current companies received $\$ 103.7 \mathrm{M}$ in external funding and $\$ 11.6 \mathrm{M}$ in sales revenue for $2013-14$.

In November 2013, in partnership with USF's Center for Entrepreneurship, the Florida High Tech Corridor Council (The Corridor) and Hillsborough County, USF launched the Student Innovation Incubator, with 40 student-led companies vying for 15 spots in the first cohort to enter the collaborative, multidisciplinary environment for growing their businesses.

\section{INCREASE COLLABORATION AND EXTERNAL SUPPORT FOR RESEARCH ACTIVTYY}

USF research enjoys broad external support. Of USF's total \$428M in external research funding in 2014, nearly half came from community partnerships, mostly from private or foundation partners. Currently, USF has more than 200 active collaborative agreements in more than 60 countries with more than 170 institutions around the world, laying the foundation for the development of strengthening and enriching international educational and research experiences for both faculty and students.

The university also has numerous partnerships with hospitals and not-for-profit organizations in the metropolitan Tampa Bay area that provide for collaboration through shared facilities, faculty and equipment. In addition to partnerships for medical research and training with the $\mathrm{H}$. Lee Moffitt Cancer Center \& Research Institute, Tampa General Hospital, All Children's Hospital, and the James A. Haley Veterans Hospital, USF's affiliate partnerships with Mote Marine Laboratory, Draper Laboratory and others have increased research capacities and economic development. For example, in the Draper Bioengineering Center, housed in the USF Research Park, researchers work on funded projects with global health faculty. New partners continue to relocate to the USF Research Park, such as Lion Biotechnologies, which is developing novel cancer immunotherapies.

USFSP also attracts significant support for research activities from outside entities. The College of Education has received close to $\$ 2.2 \mathrm{M}$ in new or repeat grants from the Florida College of Education. USFSP also received a $\$ 1 M$ SunSense grant from Duke Energy to install solar panels on the USFSP parking garage and to study solar energy generation and storage options. 
At USF Sarasota-Manatee, collaborations are key. These include the College of Education's Partnership for Arts-Integrated Teaching Center with organizations such as the Lincoln Center Institute Imagination Conversations, Institute for the Arts in Education, Perlman Music Festival, Any Given Child, and the Kennedy Center. USF Sarasota-Manatee also partners with: Sarasota Sister Cities to host the International Sustainability Conference; the Florida Creativity Coalition, LLC, to support the Florida Creativity Weekend, to support innovation and problem-solving; and the 2014 Regional Housing Forum, sponsored by the Florida Department of Elder Affairs.

\section{Community and Business Engagement}

\section{STRENGTHEN QUALITY AND REPUTATION OF COMMTMENT TO COMMUNITY AND BUSINESS} ENGAGEMENT

High-impact community and business engagement is another key tenet of the USF System. This is important not only for providing a strong and sustainable future for Florida's economy, but also to retain students and support timely graduation. Students benefit greatly from programs outside the classroom that connect them with future employers and encourage reflection on future goals. Those students who complement their studies with "real world" experiences are also more likely to succeed academically.

USF's Office of Community Engagement and Partnerships promotes engagement through servicelearning, internships and other activities. Service-learning opportunities are now available to students starting with their first year courses and continuing through upper-level and graduate seminars. These activities include recording oral histories, building waste-processing facilities, tutoring elementary school pupils, and many others. In 2013-14, 188 service learning course sections were offered at USF, serving 4,013 students.

USFSP works hard to cultivate relationships with partners across the city and surrounding region. As one example, he institution recently hosted Larry Langebrake, director of SRI St. Petersburg, who discussed the future of downtown St. Petersburg's Marine District. USFSP was also the host of the inaugural St Petersburg Conference on World Affairs. And USFSP continues to be the venue for the St Pete Science festival and the Tampa Bay Times Festival of Reading.

USF Sarasota-Manatee strengthened its collaboration with neighboring higher education institutions that comprise the Consortium Colleges of the Cultural Coast: Eckerd College; Florida State University/Ringling Museum and Cultural Center; New College of Florida; Ringling College of Art and Design; State College of Florida, Manatee-Sarasota; and University of South Florida Sarasota-Manatee.

\section{INCREASE LEVELS OF COMMUNTYY AND BUSINESS ENGAGEMENT}

During 2013-14, USF in Tampa completely revamped its Career Services operation - recognizing the important value of increased engagement on both student success and the institution's reputation. This included the creation of a new Assistant Vice President for Career Services, whose No. 1 job is to secure external partnerships for engagement. Additionally, responsibility for promoting internships was given to a new Director of Internships, to be supervised by the AVP for Career Services.

In the midst of this transformation, high-quality support of engagement activities remained strong as ever. Overall employer attendance at job fairs actually increased by 10 percent, while student attendance 
surged more than 30 percent. Career Services registered 1,750 new employers to the USF Employ-ABull online job database, and more than 9,000 new students registered to use the service.

This office in Tampa works closely with Career Services offices in St. Petersburg and Sarasota-Manatee to ensure that all USF System students can explore all the internship and job opportunities across the Tampa Bay region.

In addition to helping students secure a successful job, USF also works to prepare students for any financial obstacles they may face after graduation. Through a new Financial Literacy Program, which opened in August 2013, USF employs a variety of strategies to help students with a number of financial issues. In 2013-14, the program conducted seminars on budgeting and saving, establishing credit, and reading credit reports.

\section{INCREASE COMMUNTY AND BUSINESS WORKFORCE}

The USF System maintains a consistent focus on the success of its students not only for the sake of academic achievements, but most importantly to ensure a productive career path after graduation. The university works hard to support Florida's community and business workforce with talented Florida students. This begins with the Career Services offices while students are on campus, but it also occurs with a laser-focus on life beyond graduation.

USF Career Services also actively seeks partners across the community who work to keep bright students employed in the Tampa Bay region. This includes a partnership with the Education Connection, a sub-committee of the Tampa Chamber of Commerce. The partnership was created to develop workforce talent, encourage industry-leading research, and inspire meaningful relationships to create one of the most respected communities in the world.

In St. Petersburg, USFSP has established a partnership with Pasco Hernando State College. Through this partnership USFSP provides programs leading to certification and degrees in Elementary and Special Education with endorsements in Reading and English Speakers of Other Languages (ESOL) and Educational Leadership at the New Port Richey campus of Pasco Hernando State College, as well as on some of its other campuses. The newly named USFSP Kate Tiedemann College of Business continues to offer the USFSP Banking Institute to provide management training for the C1 Bank Management Associate Program in the bank's new headquarters in downtown St. Petersburg.

Through a partnership among the USF Tampa College of Business, the USF Sarasota-Manatee College of Business, and the Small Business Development Network, a regional Small Business Development Center (SBDC) opened at the teaching site at USF Sarasota-Manatee at North Port.

USF Sarasota-Manatee also works to increase the community workforce through programs for high school students. USF Sarasota-Manatee and Take Stock in Children of Sarasota initiated a yearlong College Readiness Passport Program for local juniors and seniors in high school to ensure that they are prepared for college upon graduation. Take Stock in Children aids at-risk, low-income students to ensure that they not only graduate from high school but also move on toward a successful college and working career. 


\section{Data Tables}

\section{FINANCIAL RESOURCES}

Table 1A. Education and General Revenues

Table 1B. Education and General Expenditures

Table 1C. Funding per Student FTE

Table 1D. Other Budget Entities

Table 1E. Voluntary Support of Higher Education

Table 1F. Tuition Differential Fee

PERSONNEL

Table 2A. Personnel Headcount

\section{ENROLLMENT}

Table 3A. Headcount Enrollment by Student Type

Table 3B. Full-time Equivalent (FTE) Enrollment

Table 3C. Enrollment by Method of Instruction

Table 3D. Headcount Enrollment by Military Status and Student Level

Table 3E. University Access Rate: Undergraduate Enrollment with Pell Grant

\section{UNDERGRADUATE EDUCATION}

Table 4A. Baccalaureate Degree Program Changes in AY 2013-2014

Table 4B. Retention Rates

Table 4C. Full-time, First-Time-in-College (FTIC) Six-Year Graduation Rates

Table 4D. Full- and Part-time FTIC Graduation Rates

Table 4E. AA Transfers Graduation Rates

Table 4F. Other Transfers Graduation Rates

Table 4G. Baccalaureate Degrees Awarded

Table 4H. Baccalaureate Degrees Awarded in Areas of Strategic Emphasis

Table 4I. Baccalaureate Degrees Awarded to Underrepresented Groups

Table 4J. Baccalaureate Degrees Without Excess Credit Hours

Table 4K. Undergraduate Course Offerings

Table 4L. Faculty Teaching Undergraduates

Table 4M. Student/Faculty Ratio

Table 4N. Licensure/Certification Exam: Nursing (NCLEX)

Table 4O. Post-Graduation Metrics

\section{GRADUATE EDUCATION}

Table 5A. Graduate Degree Program Changes in AY 2013-2014

Table 5B. Graduate Degrees Awarded

Table 5C. Graduate Degrees Awarded in Areas of Strategic Emphasis

Table 5D. Licensure/Certification Exams for Graduate Programs

\section{RESEARCH \& ECONOMIC DEVELOPMENT}

Table 6A. Research and Development Expenditures

Table 6B. Centers of Excellence 


\section{Section 1 - Financial Resources}

\section{TABLE 1A. University Education and General Revenues}

\begin{tabular}{lrrrrr} 
& $\begin{array}{r}\mathbf{2 0 1 0 - 1 1} \\
\text { Actual }\end{array}$ & $\begin{array}{r}\mathbf{2 0 1 1 - 1 2} \\
\text { Actual }\end{array}$ & $\begin{array}{r}\mathbf{2 0 1 2 - 1 3} \\
\text { Actual }\end{array}$ & $\begin{array}{r}\mathbf{2 0 1 3 - 1 4} \\
\text { Actual }\end{array}$ & $\begin{array}{r}\mathbf{2 0 1 4 - 1 5} \\
\text { Estimates }\end{array}$ \\
\hline MAIN OPERATIONS & & & & & \\
\hline Recurring State Funds & $\$ 262,674,613$ & $\$ 239,016,278$ & $\$ 230,779,497$ & $\$ 248,172,676$ & $\$ 276,361,482$ \\
\hline Non-Recurring State Funds & $\$ 3,873,018$ & $\$ 2,656,583$ & $-\$ 48,242,853$ & $\$ 4,203,604$ & $\$ 2,066,536$ \\
\hline Tuition & $\$ 129,324,373$ & $\$ 136,448,693$ & $\$ 141,487,748$ & $\$ 148,736,779$ & $\$ 156,587,307$ \\
\hline Tuition Differential Fee & $\$ 14,376,755$ & $\$ 22,361,250$ & $\$ 33,908,713$ & $\$ 33,418,653$ & $\$ 33,935,397$ \\
\hline Misc. Fees \& Fines & $\$ 3,364,814$ & $\$ 3,152,439$ & $\$ 2,810,903$ & $\$ 2,969,679$ & $\$ 3,673,196$ \\
\hline Phosphate Research TF & $\$ 7,330,654$ & $\$ 7,337,035$ & $\$ 0$ & $\$ 0$ & $\$ 0$ \\
\hline Federal Stimulus Funds & $\$ 17,980,176$ & $\$ 0$ & $\$ 0$ & $\$ 0$ & $\$ 0$ \\
\hline SUBTOTAL & $\$ 438,924,403$ & $\$ 410,972,278$ & $\$ 360,744,008$ & $\$ 437,501,391$ & $\$ 472,623,918$
\end{tabular}

HEALTH SCIENCE CENTER I MEDICAL SCHOOL

\begin{tabular}{lrrrrr}
\hline Recurring State Funds & $\$ 61,824,195$ & $\$ 63,127,971$ & $\$ 65,793,008$ & $\$ 71,529,136$ & $\$ 72,556,899$ \\
\hline Non-Recurring State Funds & $\$ 1,175,000$ & $\$ 250,000$ & $\$ 0$ & $\$ 1,409,562$ & $\$ 2,100,000$ \\
\hline Tuition & $\$ 32,942,009$ & $\$ 41,065,438$ & $\$ 48,203,644$ & $\$ 51,733,993$ & $\$ 52,165,514$ \\
\hline Tuition Differential Fee & $\$ 947,321$ & $\$ 1,703,379$ & $\$ 2,956,633$ & $\$ 3,248,580$ & $\$ 3,711,724$ \\
\hline Misc. Fees \& Fines & $\$ 1,280$ & $\$ 2,568$ & $\$ 41,978$ & $\$ 83,414$ & $\$ 87,858$ \\
\hline Phosphate Research TF & $\$ 0$ & $\$ 0$ & $\$ 0$ & $\$ 0$ & $\$ 0$ \\
\hline Federal Stimulus Funds & $\$ 4,351,772$ & $\$ 0$ & $\$ 0$ & $\$ 0$ & $\$ 0$ \\
\hline SUBTOTAL & $\$ 101,241,577$ & $\$ 106,149,356$ & $\$ 116,995,263$ & $\$ 128,004,685$ & $\$ 130,621,995$ \\
\multicolumn{1}{c}{ TOTAL } & $\$ 540,165,980$ & $\$ 517,121,634$ & $\$ 477,739,271$ & $\$ 565,506,076$ & $\$ 603,245,913$
\end{tabular}

Recurring State Funds: State recurring funds include general revenue and lottery education \& general (E\&G) appropriations and any administered funds provided by the state. This does not include technical adjustments or transfers made by universities after the appropriation. Source: For actual years, SUS Final Amendment Packages; for estimated year the 2013-14 Allocation Summary and Workpapers (Total E\&G general revenue \& lottery minus nonrecurring) and Board of Governors staff calculations for risk management insurance adjustments. Non-Recurring State Funds: State non-recurring funds include general revenue and lottery education \& general appropriations and any administered funds provided by the state. This does not include technical adjustments or transfers made by Universities after the appropriation - Source: non-recurring appropriations section of the annual Allocation Summary and Workpapers document and all other non-recurring budget amendments allocated later in the fiscal year. In 2013-2014, \$15 million in non-recurring state support was provided to the Board to provide grants to address targeted program areas as identified in the GAP Analysis Report prepared by the Commission on Florida Higher Education Access \& Attainment. For FY 2014-2015, these funds were reallocated to the institutions as recurring dollars to support the performance funding initiative. Tuition: Actual resident \& non-resident tuition revenues collected from students, net of fee waivers. - Source: Operating Budget, Report 625 - Schedule I-A. Tuition Differential Fee: Actual tuition differential revenues collected from undergraduate students - Source: Operating Budget, Report 625 - Schedule I-A. Miscellaneous Fees \& Fines: Other revenue collections include items such as application fees, late registration fees, library fines, miscellaneous revenues. This is the total revenue from Report 625 minus tuition and tuition differential fee revenues. This does not include local fees - Source: Operating Budget, Report 625 - Schedule I-A. Phosphate Research Trust Fund: State appropriation for the Florida Industrial and Phosphate Research Institute at the University of South Florida (for history years through 2012-13); beginning 2013-14 the Phosphate Research Trust Fund is appropriated through Florida Polytechnic University. Other Operating Trust Funds- For UF-IFAS and UF-HSC, actual revenues from the Incidental Trust Funds and Operations \& Maintenance Trust Fund are provided by the University of Florida. Source: Final Amendment Package. Federal Stimulus Funds: Non-recurring American Recovery and Reinvestment Act funds appropriated by the state - Source: SUS Final Amendment Package. 
Section 1 - Financial Resources (continued)

TABLE 1B. University Education and General Expenditures

\begin{tabular}{|c|c|c|c|c|c|}
\hline & $\begin{array}{c}2009-10 \\
\text { Actual }\end{array}$ & $\begin{array}{c}2010-11 \\
\text { Actual }\end{array}$ & $\begin{array}{c}2011-12 \\
\text { Actual }\end{array}$ & $\begin{array}{l}2012-13 \\
\text { Actual }\end{array}$ & $\begin{array}{l}\text { 2013-14 } \\
\text { Actual* }\end{array}$ \\
\hline \multicolumn{6}{|l|}{ MAIN OPERATIONS } \\
\hline Instruction/Research & $\$ 240,305,590$ & $\$ 247,614,259$ & $\$ 237,707,579$ & $\$ 287,236,489$ & $\$ 291,847,040$ \\
\hline Administration and Support & $\$ 21,579,605$ & $\$ 24,095,427$ & $\$ 23,893,443$ & $\$ 32,410,560$ & $\$ 30,296,584$ \\
\hline PO\&M & $\$ 35,121,223$ & $\$ 34,491,862$ & $\$ 35,141,676$ & $\$ 41,615,990$ & $\$ 39,965,797$ \\
\hline Student Services & $\$ 21,119,119$ & $\$ 20,347,800$ & $\$ 18,207,622$ & $\$ 16,781,322$ & $\$ 12,004,895$ \\
\hline Library/Audio Visual & $\$ 14,138,213$ & $\$ 13,010,468$ & $\$ 13,297,996$ & $\$ 10,411,967$ & $\$ 14,004,521$ \\
\hline Other & $\$ 2,857,226$ & $\$ 2,854,224$ & $\$ 6,470,660$ & $\$ 6,957,842$ & $\$ 5,869,392$ \\
\hline TOTAL & $\$ 335,120,976$ & $\$ 342,414,040$ & $\$ 334,718,976$ & $\$ 395,414,170$ & $\$ 393,988,229$ \\
\hline
\end{tabular}

HEALTH SCIENCE CENTER I MEDICAL SCHOOL

\begin{tabular}{lrrrrr}
\hline Instruction/Research & $\$ 68,082,738$ & $\$ 76,521,544$ & $\$ 76,382,108$ & $\$ 95,673,445$ & $\$ 102,295,643$ \\
\hline Administration and Support & $\$ 5,033,768$ & $\$ 6,375,343$ & $\$ 5,076,837$ & $\$ 8,132,708$ & $\$ 6,263,326$ \\
\hline PO\&M & $\$ 84,684$ & $\$ 1,373,059$ & $\$ 1,800,847$ & $\$ 7,019,397$ & $\$ 7,391,135$ \\
\hline Library/Audio Visual & $\$ 2,473,154$ & $\$ 2,437,820$ & $\$ 3,043,160$ & $\$ 2,921,295$ & $\$ 2,587,261$ \\
\hline Teaching Hospital \& Clinics & $\$ 0$ & $\$ 0$ & $\$ 0$ & $\$ 0$ & $\$ 0$ \\
Student Services, and Other & $\$ 0$ & $\$ 1,640$ & $\$ 0$ & $\$ 0$ & $\$ 0$ \\
TOTAL & $\$ 75,674,344$ & $\$ \mathbf{8 8 6 , 7 0 9 , 4 0 6}$ & $\mathbf{\$ 8 6 , 3 0 2 , 9 5 2}$ & $\$ 113,746,845$ & $\$ 118,537,365$
\end{tabular}

TOTAL

$\$ 364,094,641 \quad \$ 382,130,676 \quad \$ 374,342,907 \quad \$ 509,161,015 \quad \$ 512,525,594$

The table reports the actual and estimated amount of expenditures from revenues appropriated by the legislature for each fiscal year. The expenditures are classified by Program Component (i.e., Instruction/Research, PO\&M, Administration, etc...) for activities directly related to instruction, research and public service. The table does not include expenditures classified as non-operating expenditures (i.e., to service assetrelated debts), and therefore excludes a small portion of the amount appropriated each year by the legislature. Note*: FY 2012-2013 reflects a change in reporting expenditures from prior years due to the new carry-forward reporting requirement as reflected in the 2013-2014 SUS Operating Budget Reports. Since these expenditures will now include carry-forward expenditures, these data are no longer comparable to the current-year revenues reported in table $1 \mathrm{~A}$, or prior year expenditures in table $1 \mathrm{~B}$.

Instruction \& Research: Includes expenditures for state services related to the instructional delivery system for advanced and professional education. Includes functions such as; all activities related to credit instruction that may be applied toward a postsecondary degree or certificate; nonproject research and service performed to maintain professional effectives; individual or project research; academic computing support; academic source or curriculum development. Source: Operating Budget Summary - Expenditures by Program Activity (or Report 645). Administration \& Support Services: Expenditures related to the executive direction and leadership for university operations and those internal management services which assist and support the delivery of academic programs. Source: Operating Budget Summary - Expenditures by Program Activity (or Report 645). PO\&M: Plant Operations \& Maintenance expenditures related to the cleaning and maintenance of existing grounds, the providing of utility services, and the planning and design of future plant expansion and modification. Student Services: Includes resources related to physical, psychological, and social well-being of the student. Includes student service administration, social and cultural development, counseling and career guidance, financial aid, and student admissions and records. Other: includes Institutes and Research Centers, Radio/TV, Museums and Galleries, Intercollegiate Athletics, Academic Infrastructure Support Organizations. Source: Operating Budget Summary - Expenditures by Program Activity (or Report 645). 


\section{Section 1 - Financial Resources (continued)}

\section{TABLE 1C. State Funding per Full-Time Equivalent (FTE) Student}

\begin{tabular}{lrrrrr} 
& $\begin{array}{r}\mathbf{2 0 0 9 - 1 0} \\
\text { Actual }\end{array}$ & $\begin{array}{r}\mathbf{2 0 1 0 - 1 1} \\
\text { Actual }\end{array}$ & $\begin{array}{r}\mathbf{2 0 1 1 - 1 2} \\
\text { Actual }\end{array}$ & $\begin{array}{r}\mathbf{2 0 1 2 - 1 3} \\
\text { Actual }\end{array}$ & $\begin{array}{r}\text { 2013-14 } \\
\text { Actual }\end{array}$ \\
\hline Appropriated Funding per FTE & & & & & \\
\hline General Revenue & $\$ 5,912$ & $\$ 6,323$ & $\$ 5,656$ & $\$ 4,302$ & $\$ 6,214$ \\
Lottery Funds & $\$ 731$ & $\$ 840$ & $\$ 914$ & $\$ 693$ & $\$ 854$ \\
$\quad \begin{array}{l}\text { Tuition \& Fees } \\
\text { Other Trust Funds }\end{array}$ & $\$ 3,954$ & $\$ 4,113$ & $\$ 4,698$ & $\$ 5,169$ & $\$ 6,028$ \\
TOTAL & $\$ 712$ & $\$ 680$ & $\$ 199$ & $\$ 0$ & $\$ 0$ \\
Actual Funding per FTE & $\$ 11,309$ & $\$ 11,956$ & $\$ 11,467$ & $\$ 10,164$ & $\$ 13,096$ \\
\hline Tuition \& Fees & & & & & \\
TOTAL & $\$ 3,551$ & $\$ 3,952$ & $\$ 4,394$ & $\$ 4,877$ & $\$ 5,184$ \\
& $\$ 10,905$ & $\$ 11,795$ & $\$ 11,163$ & $\$ 9,873$ & $\$ 12,252$
\end{tabular}

Notes: (1) FTE is based on actual FTE, not funded FTE; (2) does not include Health-Science Center funds or FTE; (3) FTE for these metrics uses the standard IPEDS definition of FTE, equal to 30 credit hours for undergraduates and 24 for graduates; and (4) actual funding per student is based on actual tuition and E\&G fees (does not include local fees) collected. Sources: Appropriated totals from the annual Final Amendment Package data. Actual Student Fees from the Operating Budget 625 reports. This does not include appropriations for special units (i.e., IFAS, Health Science Centers, and Medical Schools). Tuition and fee revenues include tuition and tuition differential fee and E\&G fees (i.e., application, late registration, and library fees/fines). Other local fees that do not support E\&G activities are not included here (see Board of Governors Regulation 7.003). This data is not adjusted for inflation.

TABLE 1D. University Other Budget Entities

$\begin{array}{cc}2009-10 & 2010-11 \\ \text { Actual } & \text { Actual }\end{array}$

2011-12 Actual

$\$ 159,279,590$

$\$ 128,022,768$

$\begin{array}{ll}\$ 166,196,465 & \$ 179,066,877 \\ \$ 136,665,180 & \$ 145,862,330\end{array}$

2012-13 Actual 2013-14 Actual

\section{Auxiliary Enterprises}

Revenues

Expenditures

$\$ 115,485,207$

Contracts \& Grants

Revenues

Expenditures

$\$ 296,910,481$

$\$ 280,658,090$

$\$ 300,467,449$

$\$ 305,640,232$

$\$ 253,155,100$

$\$ 277,146,064$

$\$ 309,631,943$

$\$ 309,533,722$

$\$ 280,938,042$

$\$ 322,685,124$

\section{Local Funds}

Revenues

Expenditures

$\$ 408,521,266$

$\$ 442,397,152$

$\$ 445,195,358$

$\$ 447,961,430$

$\$ 452,561,412$

$\$ 406,432,437$

$\$ 440,842,216$

$\$ 444,874,604$

$\$ 451,386,947$

$\$ 456,000,627$

\section{Faculty Practice Plans}

$\begin{array}{llllll}\text { Revenues } & \$ 174,727,927 & \$ 183,622,430 & \$ 194,997,543 & \$ 199,933,005 & \$ 212,976,074 \\ \text { Expenditures } & \$ 173,643,913 & \$ 182,116,435 & \$ 196,288,464 & \$ 198,051,785 & \$ 126,205,106\end{array}$

Notes: Revenues do not include transfers. Expenditures do not include non-operating expenditures. Auxiliary Enterprises are self supported through fees, payments and charges. Examples include housing, food services, bookstores, parking services, health centers. Contract \& Grants resources are received from federal, state or private sources for the purposes of conducting research and public service activities. Local Funds are associated with student activity (supported by the student activity fee), student financial aid, concessions, intercollegiate athletics, technology fee, green fee, and student life \& services fee. Faculty Practice Plan revenues/receipts are funds generated from faculty practice plan activities. Faculty Practice Plan expenditures include all expenditures relating to the faculty practice plans, including transfers between other funds and/or entities. This may result in double counting in information presented within the annual report. Source: Operating Budget, Report 615. 
Section 1 - Financial Resources (continued) TABLE 1E. Voluntary Support of Higher Education

\begin{tabular}{cccccc} 
& $\mathbf{2 0 0 9 - 1 0}$ & $\mathbf{2 0 1 0 - 1 1}$ & $\mathbf{2 0 1 1 - 1 2}$ & $\mathbf{2 0 1 2 - 1 3}$ & $\mathbf{2 0 1 3 - 1 4}$ \\
\hline $\begin{array}{c}\text { Endowment Value } \\
(\$ 1000 \mathrm{~s})\end{array}$ & $\$ 295,921$ & $\$ 344,000$ & $\$ 334,100$ & $\$ 363,924$ & $\$ 417,335$ \\
\hline $\begin{array}{c}\text { Gifts Received } \\
(\$ 1000 \text { s) }\end{array}$ & $\$ 36,385$ & $\$ 81,500$ & $\$ 43,600$ & $\$ 36,520$ & $\$ 37,419$ \\
\hline $\begin{array}{c}\text { Percentage of } \\
\text { Alumni Donors }\end{array}$ & $10.2 \%$ & $10.0 \%$ & $9.9 \%$ & $9.4 \%$ & $8.9 \%$ \\
\hline
\end{tabular}

Notes: Endowment value at the end of the fiscal year, as reported in the annual NACUBO Endowment Study. Gifts Received as reported in the Council for Aid to Education's Voluntary Support of Education (VSE) survey in the section entitled "Gift Income Summary," this is the sum of the present value of all gifts (including outright and deferred gifts) received for any purpose and from all sources during the fiscal year, excluding pledges and bequests. (There's a deferred gift calculator at www.cae.org/vse.) The present value of non-cash gifts is defined as the tax deduction to the donor as allowed by the IRS. Percentage of Alumni Donors as reported in the Council for Aid to Education's Voluntary Support of Education (VSE) survey in the section entitled "Additional Details," this is the number of alumni donors divided by the total number of alumni, as of the end of the fiscal year. "Alumni," as defined in this survey, include those holding a degree from the institution as well as those who attended the institution but did not earn a degree.

\section{TABLE 1F. Tuition Differential Fees (TDF)}

\begin{tabular}{lccc} 
& $\mathbf{2 0 1 1 - 1 2}$ & $\mathbf{2 0 1 2 - 1 3}$ & $\mathbf{2 0 1 3 - 1 4}$ \\
\hline TDF Revenues Generated & $\$ 22,361,250$ & $\$ 36,865,346$ & $\$ 36,667,233$ \\
\hline Students Receiving TDF Funded Award & 5,235 & 9,224 & 9,862 \\
\hline Total Value of TDF Funded Financial Aid Awards & $\$ 1,282$ & $\$ 1,247$ & $\$ 1,217$
\end{tabular}

\section{Florida Student Assistance Grant (FSAG) Eligible Students}

\begin{tabular}{lccc}
\hline Number of Eligible Students & 8,147 & 13,431 & 10,402 \\
Number Receiving a TDF Waiver & 0 & 0 & 0 \\
\hline Total Value of TDF Waivers & $\$ 0$ & $\$ 0$ & $\$ 0$
\end{tabular}

Note: TDF Revenues Generated refers to actual tuition differential revenues collected from undergraduate students as reported on the Operating Budget, Report 625 - Schedule I-A. Students Receiving TDF Funded Award reports the number of unduplicated students who have received a financial aid award that was funded by tuition differential revenues. Value of TDF Funded Award refers to the average value of financial aid awards funded by the the Tuition Differential Fee funds. Florida Student Assistance Grant (FSAG) Eligible Students: Number of Eligible Students refers to total annual unduplicated count of undergraduates at the institution who are eligible for FSAG in the academic year, whether or not they received FSAG awards. Number Receiving a TDF Waiver refers to annual unduplicated count of FSAG-eligible students receiving a waiver, partial or full, of the tuition differential fees at the institution during the academic year, regardless of the reason for the waiver. Value of TDF Waivers refers to the average value of waivers provided to FSAG-eligible undergraduates at the institution during the academic year, regardless of the reason for the waiver. 


\section{Section 2 - Personnel}

TABLE 2A. Personnel Headcount (in Fall term only)

\begin{tabular}{lccccc} 
& $\mathbf{2 0 0 9}$ & $\mathbf{2 0 1 0}$ & $\mathbf{2 0 1 1}$ & $\mathbf{2 0 1 2}$ & $\mathbf{2 0 1 3}$ \\
\hline Full-time Employees & & & & & \\
\hline Tenured Faculty & 747 & 760 & 755 & 733 & 790 \\
Tenure-track Faculty & 349 & 352 & 387 & 375 & 335 \\
Non-Tenure Track Faculty & 492 & 510 & 501 & 521 & 922 \\
Instructors Without Faculty Status & 0 & 0 & 0 & 0 & 0 \\
Graduate Assistants/Associates & 0 & 0 & 0 & 0 & 0 \\
Non-Instructional Employees & 4,032 & 4,210 & 4,403 & 4,281 & 5,158 \\
\hline FULL-TIME SUBTOTAL & $\mathbf{5 , 6 2 0}$ & $\mathbf{5 , 8 3 1}$ & $\mathbf{6 , 0 4 6}$ & $\mathbf{5 , 9 1 0}$ & $\mathbf{7 , 2 0 5}$ \\
& & & & & \\
Part-time Employees & & & & & \\
\hline Tenured Faculty & 58 & 54 & 47 & 56 & 26 \\
Tenure-track Faculty & 21 & 25 & 21 & 19 & 13 \\
Non-Tenure Track Faculty & 145 & 231 & 381 & 728 & 781 \\
Instructors Without Faculty Status & 0 & 3 & 0 & 0 & 0 \\
Graduate Assistants/Associates & 1,863 & 2,071 & 2,059 & 2,026 & 2,096 \\
Non-Instructional Employees & 311 & 318 & 211 & 778 & 82 \\
\hline PART-TIME SUBTOTAL & $\mathbf{2 , 3 9 8}$ & $\mathbf{2 , 6 9 9}$ & $\mathbf{2 , 7 1 9}$ & $\mathbf{3 , 6 0 7}$ & $\mathbf{2 , 9 9 8}$ \\
\hline \multicolumn{1}{c}{ TOTAL } & $\mathbf{8 , 0 1 8}$ & $\mathbf{8 , 5 3 0}$ & $\mathbf{8 , 7 6 5}$ & $\mathbf{9 , 5 1 7}$ & $\mathbf{1 0 , 2 0 3}$
\end{tabular}

Note: This table is based on the annual IPEDS Human Resources Survey, and provides full- and part-time medical and non-medical staff by faculty status and primary function/occupational activity. Tenured and Tenure-Track Faculty include those categorized within instruction, research, or public service. Non-Tenure Track Faculty includes adjunct faculty (on annual and less than annual contracts) and faculty on multi-year contracts categorized within instruction, research, or public service. Instructors Without Faculty Status includes postdoctoral research associates, and individuals hired as a staff member primarily to do research on a 3-year contract without tenure eligibility categorized within instruction, research, or public service. Non-Instructional Employees includes all executive, administrative and managerial positions regardless of faculty status; as well as, other support and service positions regardless of faculty status. Note: The universities vary on how they classify adjuncts (some include them as non-tenure track faculty while others do not consider them faculty and report them as instructors without faculty status) and part-time non-instructional employees. 


\section{Section 3 - Enrollment}

TABLE 3A. Headcount Enrollment by Student Type and Level

\begin{tabular}{lrrrrr} 
& Fall 2009 & Fall 2010 & Fall 2011 & Fall 2012 & Fall 2013 \\
\hline TOTAL & 47,307 & 47,800 & 47,362 & 47,854 & 48,315
\end{tabular}

UNDERGRADUATE

\begin{tabular}{lrrrrr}
\hline FTIC (Regular Admit) & 16,861 & 17,549 & 17,043 & 16,930 & 17,063 \\
FTIC (Profile Admit) & 281 & 227 & 196 & 173 & 155 \\
AA Transfers & 9,769 & 10,534 & 11,053 & 11,210 & 11,056 \\
Other Transfers & 8,923 & 7,982 & 7,471 & 7,844 & 7,736 \\
\hline Subtotal & $\mathbf{3 5 , 8 3 4}$ & $\mathbf{3 6 , 2 9 2}$ & $\mathbf{3 5 , 7 6 3}$ & $\mathbf{3 6 , 1 5 7}$ & $\mathbf{3 6 , 0 1 0}$
\end{tabular}

GRADUATE

\begin{tabular}{lrrrrr}
\hline Master's & 6,538 & 6,522 & 6,395 & 6,481 & 6,806 \\
Research Doctoral & 2,141 & 2,289 & 2,362 & 2,336 & 2,294 \\
Professional Doctoral & 595 & 604 & 676 & 905 & $\mathbf{1 , 2 2 0}$ \\
\hline Dentistry & 0 & 0 & 0 & 0 & 0 \\
Law & 0 & 0 & 0 & 0 & 0 \\
Medicine & 482 & 473 & 502 & 549 & 620 \\
Nursing Practice & 39 & 32 & 27 & 30 & 43 \\
Pharmacy & 0 & 0 & 53 & 119 & 225 \\
Physical Therapist & 74 & 99 & 94 & 207 & 332 \\
Veterinary Medicine & 0 & 0 & 0 & 0 & 0 \\
Other & 0 & 0 & 0 & 0 & 0 \\
\hline Subtotal & $\mathbf{9 , 2 7 4}$ & $\mathbf{9 , 4 1 5}$ & $\mathbf{9 , 4 3 3}$ & $\mathbf{9 , 7 2 2}$ & $\mathbf{1 0 , 3 2 0}$
\end{tabular}

UNCLASSIFIED

$2,199 \quad 2,093 \quad 2,166 \quad 1,975 \quad 1,985$

Note: This table reports the number of students enrolled at the university by student type categories. The determination for undergraduate, graduate and unclassified is based on the institutional class level values. Unclassified refers to a student who has not yet been formally admitted into a degree program but is enrolled. The student type for undergraduates is based on the Type of Student at Time of Most Recent Admission. The student type for graduates is based on the degree that is sought and the student CIP code. 


\section{Section 3 - Enrollment (continued)}

TABLE 3B. Full-Time Equivalent (FTE) Enrollment [State Fundable only]

2011-12

StateFunded

2012-13
2013-14

\begin{tabular}{|c|c|c|c|c|c|c|}
\hline & $\begin{array}{l}\text { State- } \\
\text { Funded }\end{array}$ & Actual & $\begin{array}{l}\text { State- } \\
\text { Funded }\end{array}$ & Actual & $\begin{array}{l}\text { State- } \\
\text { Funded }\end{array}$ & Actual \\
\hline \multicolumn{7}{|c|}{ FLORIDA RESIDENTS } \\
\hline Lower-Division & 9,378 & 9,291 & 9,378 & 9,126 & & 8,906 \\
\hline Upper-Division & 13,361 & 14,617 & 13,361 & 14,688 & & 14,212 \\
\hline Master's (GRAD I) & 3,680 & 3,503 & 3,680 & 3,447 & & 3,437 \\
\hline Doctoral (GRAD II) & 854 & 978 & 854 & 962 & & 945 \\
\hline Subtotal & 27,273 & 28,389 & 27,273 & 28,223 & & 27,499 \\
\hline
\end{tabular}

\section{NON-FLORIDA RESIDENTS}

\begin{tabular}{|c|c|c|c|}
\hline Lower-Division & 504 & 633 & 771 \\
\hline Upper-Division & 507 & 589 & 717 \\
\hline Master's (GRAD I) & 542 & 643 & 809 \\
\hline Doctoral (GRAD II) & 579 & 632 & 639 \\
\hline Subtotal & 2,132 & 2,497 & 2,935 \\
\hline
\end{tabular}

\section{TOTAL FTE}

\begin{tabular}{lrr|rr|rr}
\hline Lower-Division &. & 9,796 &. & 9,759 & 9,764 & 9,677 \\
Upper-Division &. & 15,124 &. & 15,278 & 13,751 & 14,928 \\
Master's (GRAD I) &. & 4,045 &. & 4,090 & 4,298 & 4,246 \\
Doctoral (GRAD II) &. & 1,553 &. & 1,594 & 860 & $\mathbf{1 , 5 8 4}$ \\
\hline Total & $\mathbf{2 8 , 6 7 3}$ & $\mathbf{3 0 , 5 1 8}$ & $\mathbf{2 8 , 6 7 3}$ & $\mathbf{3 0 , 7 2 0}$ & $\mathbf{2 8 , 6 7 3}$ & $\mathbf{3 0 , 4 3 4}$ \\
\hline Total (US Definition) & $\mathbf{3 8 , 2 3 1}$ & $\mathbf{4 0 , 6 9 1}$ & $\mathbf{3 8 , 2 3 1}$ & $\mathbf{4 0 , 9 6 0}$ & $\mathbf{3 8 , 2 3 1}$ & $\mathbf{4 0 , 5 7 9}$ \\
\hline
\end{tabular}

Notes: Full-time Equivalent (FTE) student is a measure of instructional effort (and student activity) that is based on the number of credit hours that students enroll by course level. FTE is based on the Florida definition, which divides undergraduate credit hours by 40 and graduate credit hours by 32 (US definition based on Undergraduate FTE = 30 and Graduate FTE = 24 credit hours). In 2013-14, the Florida Legislature chose to no longer separate funded non-resident FTE from funded resident FTE. Funded enrollment as reported in the General Appropriations Act and Board of Governors' Allocation Summary. Actual enrollment only reports 'state-fundable' FTE as reported by Universities to the Board of Governors in the Student Instruction File (SIF). Totals are actual and may not equal sum of reported student levels due to rounding of student level FTE. Total FTE are equal in tables $3 \mathrm{~B}$ and $3 \mathrm{C}$. 


\section{Section 3 - Enrollment (continued)}

TABLE 3C. Full-Time Equivalent (FTE) Enrollment by Method of Instruction

2010-11

2011-12

2012-13

2013-14

\section{TRADITIONAL}

Lower-Division

8,301

8,140

8,134

8,213

Upper-Division

11,259

Master's (GRAD 1)

2,888

Doctoral (GRAD 2)

Total

1,453

23,901

22

330

134

Master's (GRAD 1)

Doctoral (GRAD 2)

Total
10,948

2,863

1,491

23,442
10,668

2,796

1,519

23,117
10,206

2,967

1,494

22,880
HYBRID
Lower-Division

Upper-Division

9

495

48

352

147

5

489

97

390

140

8

635
67

355

158

10

589

\section{DISTANCE LEARNING}

$\begin{array}{lrrrr}\text { Lower-Division } & 1,557 & 1,607 & 1,528 & 1,396 \\ \text { Upper-Division } & 3,411 & 3,821 & 4,220 & 4,367 \\ \text { Master's (GRAD 1) } & 1,108 & 1,034 & 1,154 & 1,121 \\ \text { Doctoral (GRAD 2) } & 50 & 62 & 67 & 81 \\ \text { Total } & \mathbf{6 , 1 2 6} & \mathbf{5 , 0 7 0} & \mathbf{6 , 9 6 9} & \mathbf{6 , 9 6 5}\end{array}$

\section{TOTAL}

Lower-Division
Upper-Division
Master's (GRAD 1)
Doctoral (GRAD 2)
Total

Total

9,880
15,000
4,130
1,512
30,522

9,795

15,121

4,044

1,558

30,518
9,759

15,278

4,090

1,594

30,720
9,677

14,928

4,246

1,584

30,434

Note: Full-time Equivalent (FTE) student is a measure of instructional effort (and student activity) that is based on the number of credit hours that students enroll by course level. FTE is based on the Florida definition, which divides undergraduate credit hours by 40 and graduate credit hours by 32. Distance Learning is a course in which at least 80 percent of the direct instruction of the course is delivered using some form of technology when the student and instructor are separated by time or space, or both (per 1009.24(17), F.S.). Hybrid is a course where $50 \%$ to $79 \%$ of the instruction is delivered using some form of technology, when the student and instructor are separated by time or space, or both (per SUDS data element 2052). Traditional (and Technology Enhanced) refers to primarily face to face instruction utilizing some form of technology for delivery of supplemental course materials for no more than $49 \%$ of instruction (per SUDS data element 2052). Totals are actual and may not equal sum of reported student levels due to rounding of student level FTE. Total FTE are equal in tables $3 B$ and $3 \mathrm{C}$. 


\section{Section 3 - Enrollment (continued)}

TABLE 3D. Headcount Enrollment by Military Status and Student Level

Fall 2010

Fall 2011

Fall 2012

Fall 2013

\begin{tabular}{|c|c|c|c|c|}
\hline \multicolumn{5}{|l|}{ MILITARY } \\
\hline Unclassified & 29 & 36 & 27 & 29 \\
\hline Undergraduate & 850 & 933 & 1,014 & 1,025 \\
\hline Master's (GRAD 1) & 148 & 153 & 178 & 187 \\
\hline Doctoral (GRAD 2) & 18 & 26 & 27 & 18 \\
\hline Subtotal & 1,045 & 1,148 & 1,246 & 1,259 \\
\hline \multicolumn{5}{|c|}{ ELIGIBLE DEPENDENT } \\
\hline Unclassified & 3 & 1 & 5 & 1 \\
\hline Undergraduate & 168 & 174 & 190 & 198 \\
\hline Master's (GRAD 1) & 14 & 14 & 15 & 20 \\
\hline Doctoral (GRAD 2) & & & 1 & 1 \\
\hline Subtotal & 185 & 189 & 211 & 220 \\
\hline \multicolumn{5}{|l|}{ NON-MILITARY } \\
\hline Unclassified & 2,061 & 2,128 & 1,942 & 1,953 \\
\hline Undergraduate & 35,274 & 34,657 & 34,954 & 34,789 \\
\hline Master's (GRAD 1) & 6,804 & 6,755 & 6,937 & 7,434 \\
\hline Doctoral (GRAD 2) & 2,431 & 2,485 & 2,564 & 2,660 \\
\hline Subtotal & 46,570 & 46,025 & 46,397 & 46,836 \\
\hline TOTAL & 47,800 & 47,362 & 47,854 & 48,315 \\
\hline
\end{tabular}

Note: This table provides trend data on the number of students enrolled based on their military status. Military includes students who were classified as Active Duty, Veterans, National Guard, or Reservist.. Eligible Dependents includes students who were classified as eligible dependents (dependents who received veteran's benefits). Non-Military includes all other students.

TABLE 3E. University Access Rate: Undergraduate Enrollment with Pell Grant

\begin{tabular}{lccccc} 
& Fall 2009 & Fall 2010 & Fall 2011 & Fall 2012 & Fall 2013 \\
\hline Pell Grant Recipients & 11,694 & 13,961 & 14,818 & 14,884 & 14,754 \\
\hline Percent with Pell Grant & $33 \%$ & $39 \%$ & $42 \%$ & $42 \%$ & $42 \%$
\end{tabular}

Note: This table reports the University's Access Rate, which is a measure of the percentage of undergraduate students who have received a federal Pell grant award during a given Fall term. The top row reports the number of students who received a Pell Grant award. The bottom row provides the percentage of eligible students that received a Pell Grant award. 


\section{Section 4 - Undergraduate Education}

TABLE 4A. Baccalaureate Degree Program Changes in AY 2013-14

\begin{tabular}{|c|c|c|c|c|c|}
\hline Title of Program & $\begin{array}{c}\text { Six-digit } \\
\text { CIP } \\
\text { Code }\end{array}$ & $\begin{array}{c}\text { Degree } \\
\text { Level }\end{array}$ & $\begin{array}{l}\text { Date of } \\
\text { UBOT } \\
\text { Action }\end{array}$ & $\begin{array}{l}\text { Starting } \\
\text { or Ending } \\
\text { Term }\end{array}$ & Comments \\
\hline \multicolumn{6}{|l|}{ New Programs } \\
\hline Biology (Sarasota-Manatee) & 26.0101 & Bachelors & Jun 6/13 & 2014 FALL & \\
\hline \multicolumn{6}{|l|}{ Terminated Programs } \\
\hline Interdisciplinary Studies (Tampa) & 30.9999 & Bachelors & Mar 6/14 & 2014 SUMMER & \\
\hline Business Managerial Economics (Tampa) & 52.0601 & Bachelors & Mar 6/14 & 2014 SUMMER & \\
\hline Elementary Ed (St. Petersburg) & 13.1202 & Bachelors & Mar 6/14 & 2014 SUMMER & \\
\hline Special Education (St. Petersburg) & 13.1001 & Bachelors & Mar 6/14 & 2014 SUMMER & \\
\hline Social Sciences, General (Lakeland) & 45.0101 & Bachelors & Jun $6 / 13$ & 2013 SUMMER & \\
\hline Psychology, General (Lakeland) & 42.0101 & Bachelors & Jun $6 / 13$ & 2013 SUMMER & \\
\hline Marketing Management (Lakeland) & 52.1401 & Bachelors & Jun $6 / 13$ & 2013 SUMMER & \\
\hline Information Technology (Lakeland) & 11.0103 & Bachelors & Jun 6/13 & 2013 SUMMER & \\
\hline Industrial Engineering (Lakeland) & 14.3501 & Bachelors & Jun 6/13 & 2013 SUMMER & \\
\hline $\begin{array}{l}\text { Elementary Education \& Teaching } \\
\text { (Lakeland) }\end{array}$ & 13.1202 & Bachelors & Jun $6 / 13$ & 2013 SUMMER & \\
\hline Criminology (Lakeland) & 45.0401 & Bachelors & Jun 6/13 & 2013 SUMMER & \\
\hline $\begin{array}{l}\text { Business Administration and Management, } \\
\text { General (Lakeland) }\end{array}$ & 52.0201 & Bachelors & Jun $6 / 13$ & 2013 SUMMER & \\
\hline Applied Science (Lakeland) & 24.0102 & Bachelors & Jun $6 / 13$ & 2013 SUMMER & \\
\hline Business, General (Lakeland) & 52.0101 & Bachelors & Jun $6 / 13$ & 2013 SUMMER & \\
\hline
\end{tabular}

\section{Programs Suspended for New Enrollments}

\begin{tabular}{|l|c|c|c|c}
\hline Information Science/Studies & 11.0401 & Bachelors & - & 2010 FALL
\end{tabular}

\section{New Programs Considered By University But Not Approved}

None

Note: This table does not include new majors or concentrations added under an existing degree program CIP Code. This table reports the new and terminated program changes based on Board action dates between May 5, 2013 and May 4, 2014.New Programs are proposed new degree programs that have been completely through the approval process at the university and, if appropriate, the Board of Governors. Does not include new majors or concentrations added under an existing degree program CIP Code. Terminated Programs are degree programs for which the entire CIP Code has been terminated and removed from the university's inventory of degree programs. Does not include majors or concentrations terminated under an existing degree program CIP Code if the code is to remain active on the academic degree inventory. Programs Suspended for New Enrollments are degree programs for which enrollments have been temporarily suspended for the entire CIP Code, but the program CIP Code has not been terminated. Does not include majors or concentrations suspended under an existing degree program CIP Code if the code is to remain active on the academic degree inventory and new enrollments in any active major will be reported. Programs included in this list may have been suspended for new enrollments sometime in the past and have continued to be suspended at least one term of this academic year.New Programs Considered by University But Not Approved includes any programs considered by the university board of trustees, or any committee of the board, but not approved for implementation. Also include any programs that were returned prior to board consideration by the university administration for additional development, significant revisions, or reconceptualization; regardless of whether the proposal was eventually taken to the university board for approval. Count the returns once per program, not multiple times the proposal was returned for revisions, unless there is a total re-conceptualization that brings forward a substantially different program in a different CIP Code. 


\section{Section 4 - Undergraduate Education (continued)}

\section{TABLE 4B. Full-time, First-Time-in-College (FTIC) Retention Rates} Retained in the Second Fall Term at Same University

\begin{tabular}{cccccc} 
& $\mathbf{2 0 0 9 - 1 0}$ & $\mathbf{2 0 1 0 - 1 1}$ & $\mathbf{2 0 1 1 - 1 2}$ & $\mathbf{2 0 1 2 - 1 3}$ & $\begin{array}{c}\mathbf{2 0 1 3 - 1 4} \\
\text { Preliminary }\end{array}$ \\
\hline Cohort Size & 4,304 & 4,947 & 4,027 & 4,508 & 4,490 \\
\hline \% Retained & $87 \%$ & $85 \%$ & $86 \%$ & $87 \%$ & $87 \%$ \\
\hline $\begin{array}{c}\text { \% Retained } \\
\text { with GPA of 2.0 or higher }\end{array}$ & $83 \%$ & $81 \%$ & $84 \%$ & $84 \%$ & $85 \%$
\end{tabular}

Notes: Cohorts are based on undergraduate students who enter the institution in the Fall term (or Summer term and continue into the Fall term). Percent Retained is based on student enrollment in the Fall term following their first year. Percent Retained with GPA Above $\mathbf{2 . 0}$ is based on student enrollment in the Fall term following their first years for those students with a GPA of 2.0 or higher at the end of their first year (Fall, Spring, Summer). The most recent year of Retention data is based on preliminary data (SIFP file) that is comparable to the final data (SIF file) but may be revised in the following years based on changes in student cohorts. Note: The historical retention rates with GPAs of 2 or higher have been revised since the 2012-13 Accountability report to fix an error that impacted every institutions rates.

\section{TABLE 4C. Full-time, First-Time-in-College (FTIC) Six-Year Graduation Rates}

\begin{tabular}{cccccc} 
Term of Entry & $\mathbf{2 0 0 4 - 1 0}$ & $\mathbf{2 0 0 5 - 1 1}$ & $\mathbf{2 0 0 6 - 1 2}$ & $\mathbf{2 0 0 7 - 1 3}$ & $\begin{array}{c}\mathbf{2 0 0 8 - 1 4} \\
\text { Preliminary }\end{array}$ \\
\hline Cohort Size & 4,140 & 4,101 & 4,271 & 3,984 & 4,395 \\
\hline$\%$ Graduated & $53 \%$ & $53 \%$ & $57 \%$ & $64 \%$ & $66 \%$ \\
\hline$\%$ Still Enrolled & $9 \%$ & $9 \%$ & $9 \%$ & $7 \%$ & $6 \%$ \\
\hline$\%$ Success Rate & $62 \%$ & $62 \%$ & $66 \%$ & $71 \%$ & $72 \%$
\end{tabular}

Notes: Cohorts are based on undergraduate students who enter the institution in the Fall term (or Summer term and continue into the Fall term). Percent Graduated is based on federal rate and does not include students who originally enroll as part-time students, or who transfer into the institution. This metric complies with the requirements of the federal Student Right to Know Act that requires institutions to report the completion status at 150\% of normal time (or six years). Success Rate measures the percentage of an initial cohort of students who have either graduated or are still enrolled at the same university. Since degrees can be awarded after the last semester of coursework, the most recent year of data in this table provides preliminary data that may change with the addition of "late degrees". Late degrees reported in conjunction with the IPEDS Graduation Rate Survey due in mid-April will be reflected in the following year. 


\section{Section 4 - Undergraduate Education (continued)}

TABLE 4D. FTIC Graduation Rates (includes Full-and Part-time students)

\begin{tabular}{lccccc}
$\mathbf{4 - \text { Year Rates }}$ & $\mathbf{2 0 0 6 - 1 0}$ & $\mathbf{2 0 0 7 - 1 1}$ & $\mathbf{2 0 0 8 - 1 2}$ & $\mathbf{2 0 0 9 - 1 3}$ & $\begin{array}{c}\mathbf{2 0 1 0 - 1 4} \\
\text { Preliminary }\end{array}$ \\
\hline Cohort Size & 4,468 & 4,185 & 4,482 & 4,348 & 4,996 \\
Same University & $28 \%$ & $35 \%$ & $37 \%$ & $42 \%$ & $43 \%$ \\
\hline Other University in SUS & $1 \%$ & $1 \%$ & $1 \%$ & $2 \%$ & $2 \%$ \\
\hline Total from System & $30 \%$ & $36 \%$ & $38 \%$ & $43 \%$ & $45 \%$
\end{tabular}

\begin{tabular}{lccccc}
$\mathbf{6}-$ Year Rates & $\mathbf{2 0 0 4 - 1 0}$ & $\mathbf{2 0 0 5 - 1 1}$ & $\mathbf{2 0 0 6 - 1 2}$ & $\mathbf{2 0 0 7 - 1 3}$ & $\begin{array}{c}\mathbf{2 0 0 8 - 1 4} \\
\text { Preliminary }\end{array}$ \\
\hline Cohort Size & 4,669 & 4,424 & 4,468 & 4,185 & 4,482 \\
Same University & $52 \%$ & $52 \%$ & $56 \%$ & $63 \%$ & $65 \%$ \\
\hline Other University in SUS & $5 \%$ & $4 \%$ & $4 \%$ & $3 \%$ & $4 \%$ \\
\hline Total from System & $57 \%$ & $56 \%$ & $60 \%$ & $67 \%$ & $69 \%$
\end{tabular}

Notes: Cohort size are based on undergraduate students who enter the institution in the Fall term (or Summer term and continue into the Fall term). Firsttime-in-college (FTIC) cohort is defined as undergraduates entering in fall term (or summer continuing to fall) with fewer than 12 hours earned after high school graduation. Students of degree programs longer than four years (eg, PharmD) are included in the cohorts. The initial cohorts can be revised to remove students, who have allowable exclusions as defined by IPEDS, from the cohort. Graduates are students in the cohort who have graduated by the summer term in their fourth or sixth year. Degree data often includes 'late degrees' which are degrees that were awarded in a previous term, but reported to SUDS later; so, the most recent year of data in this table only provides preliminary graduation rate data that may change with the addition of "late degrees". Late degrees reported in conjunction with the IPEDS Graduation Rate Survey due in mid-February will be reflected in the following year. Same University provides data for students in the cohort who graduated from the same institution. Other University in SUS provides data for students in the cohort who graduated from a different State University System of Florida institution. These data do not report students in the cohort who did not graduate from the SUS, but did graduate from another institution outside the State University System of Florida. 
Section 4 - Undergraduate Education (continued)

TABLE 4E. AA Transfer Graduation Rates

\begin{tabular}{|c|c|c|c|c|c|}
\hline 2 - Year Rates & 2008-10 & 2009-11 & 2010-12 & 2011-13 & $\begin{array}{l}\text { 2012-14 } \\
\text { Preliminary }\end{array}$ \\
\hline Cohort Size & 2,536 & 2,333 & 2,484 & 2,609 & 2,527 \\
\hline Same University & $25 \%$ & $29 \%$ & $28 \%$ & $28 \%$ & $29 \%$ \\
\hline Other SUS University & $0 \%$ & $0 \%$ & $0 \%$ & $0 \%$ & $0 \%$ \\
\hline State University System & $26 \%$ & $29 \%$ & $28 \%$ & $28 \%$ & $29 \%$ \\
\hline 4- Year Rates & 2006-10 & 2007-11 & 2008-12 & 2009-13 & $\begin{array}{c}2010-14 \\
\text { Preliminary }\end{array}$ \\
\hline Cohort Size & 2,009 & 2,216 & 2,536 & 2,333 & 2,484 \\
\hline Same University & $64 \%$ & $64 \%$ & $66 \%$ & $69 \%$ & $67 \%$ \\
\hline Other SUS University & $1 \%$ & $1 \%$ & $1 \%$ & $1 \%$ & $1 \%$ \\
\hline State University System & $65 \%$ & $66 \%$ & $67 \%$ & $70 \%$ & $68 \%$ \\
\hline
\end{tabular}

Notes: AA Transfer cohort is defined as undergraduates entering in the fall term (or summer continuing to fall) and having earned an AA degree from an institution in the Florida College System. (1) Cohorts are based on undergraduate students who enter the institution in the Fall term (or Summer term and continue into the Fall term); (2) Success Rate measures the percentage of an initial cohort of students who have either graduated or are still enrolled; (3) since degrees can be awarded after the last semester of coursework, the most recent year of data in this table provides preliminary graduation rate data that may change with the addition of "late degrees". Late degrees reported in conjunction with the IPEDS Graduation Rate Survey due in mid-April will be reflected in the following year.

\section{TABLE 4F. Other Transfer Graduation Rates}

\begin{tabular}{lccccc}
$\mathbf{5}$ - Year Rates & $\mathbf{2 0 0 5 - 1 0}$ & $\mathbf{2 0 0 6 - 1 1}$ & $\mathbf{2 0 0 7 - 1 2}$ & $\mathbf{2 0 0 8 - 1 3}$ & $\begin{array}{c}\mathbf{2 0 0 8 - 1 4} \\
\text { Preliminary }\end{array}$ \\
\hline Cohort Size & 2,498 & 2,592 & 2,842 & 2,257 & 2,654 \\
Same University & $54 \%$ & $60 \%$ & $60 \%$ & $65 \%$ & $63 \%$ \\
\hline Other SUS University & $2 \%$ & $2 \%$ & $2 \%$ & $1 \%$ & $1 \%$ \\
\hline State University System & $55 \%$ & $62 \%$ & $61 \%$ & $66 \%$ & $65 \%$
\end{tabular}

Notes: (1) Cohorts are based on undergraduate students who enter the institution in the Fall term (or Summer term and continue into the Fall term); (2) Success Rate measures the percentage of an initial cohort of students who have either graduated or are still enrolled; (3) since degrees can be awarded after the last semester of coursework, the most recent year of data in this table provides preliminary graduation rate data that may change with the addition of "late degrees". Late degrees reported in conjunction with the IPEDS Graduation Rate Survey due in mid-April will be reflected in the following year. 


\section{Section 4 - Undergraduate Education (continued)} TABLE 4G. Baccalaureate Degrees Awarded

\begin{tabular}{lccccc} 
& $\mathbf{2 0 0 9 - 1 0}$ & $\mathbf{2 0 1 0 - 1 1}$ & $\mathbf{2 0 1 1 - 1 2}$ & $\mathbf{2 0 1 2 - 1 3}$ & $\mathbf{2 0 1 3 - 1 4}$ \\
\hline TOTAL (First Majors) & 7,890 & 8,190 & 8,827 & 8,999 & 9,390 \\
TOTAL (Second Majors) & 139 & 147 & 210 & 198 & 213
\end{tabular}

Note: This table reports the number of degrees awarded by academic year. First Majors include the most common scenario of one student earning one degree in one Classification of Instructional Programs (CIP) code. In those cases where a student earns a baccalaureate degree under two different degree CIPs, a distinction is made between "dual degrees" and "dual majors." Also included in first majors are "dual degrees" which are counted as separate degrees (i.e., counted twice). In these cases, both degree CIPs receive a "degree fraction" of 1.0. Second Majors include all dual/second majors (i.e., degree CIP receive a degree fraction that is less than 1). The calculation of degree fractions is made according to each institution's criteria. The calculation for the number of second majors rounds each degree CIP's fraction of a degree up to 1 and then sums the total. Second Majors are typically used when providing degree information by discipline/CIP, to better conveys the number of graduates who have specific skill sets associated with each discipline. USF and BOG data have slight differences in the number of degrees awarded - the data presented above are from the State University Database System (SUDS).

\section{TABLE 4H. Baccalaureate Degrees in Programs of Strategic Emphasis (PSE)} [Includes Second Majors]

\begin{tabular}{lccccc} 
& $\mathbf{2 0 0 9 - 1 0}$ & $\mathbf{2 0 1 0 - 1 1}$ & $\mathbf{2 0 1 1 - 1 2}$ & $\mathbf{2 0 1 2 - 1 3}$ & $\mathbf{2 0 1 3 - 1 4}$ \\
\hline STEM & 1,535 & 1,635 & 1,897 & 2,071 & 2,064 \\
\hline HEALTH & 444 & 446 & 708 & 895 & 1,158 \\
\hline GLOBALIZATION & 229 & 243 & 284 & 249 & 289 \\
\hline EDUCATION & 793 & 753 & 689 & 643 & 641 \\
\hline GAP ANALYSIS & 716 & 743 & 787 & 699 & 747 \\
\hline SUBTOTAL & $\mathbf{3 , 7 1 7}$ & $\mathbf{3 , 8 2 0}$ & $\mathbf{4 , 3 6 5}$ & $\mathbf{4 , 5 5 7}$ & $\mathbf{4 , 8 9 9}$ \\
\hline PSE PERCENT OF TOTAL & $\mathbf{4 6 \%}$ & $\mathbf{4 6 \%}$ & $\mathbf{4 8 \%}$ & $\mathbf{5 0 \%}$ & $\mathbf{5 1 \%}$
\end{tabular}

Notes: This is a count of baccalaureate degrees awarded within specific Programs of Strategic Emphasis, as determined by the Board of Governors staff with consultation with business and industry groups and input from universities - for more information see:

http://www.flbog.edu/pressroom/strategic emphasis/. The Board of Governors revised the list of Programs of Strategic Emphasis in November 2013, and the new categories were applied to the historical degrees. A student who has multiple majors in the subset of targeted Classification of Instruction Program codes will be counted twice (i.e., double-majors are included). USF and BOG data have slight differences in the number of degrees awarded - the data presented above are from the State University Database System (SUDS). 


\section{Section 4 - Undergraduate Education (continued)}

\section{TABLE 4I. Baccalaureate Degrees Awarded to Underrepresented Groups}

$\begin{array}{lllll}2009-10 & 2010-11 & 2011-12 & 2012-13 & 2013-14\end{array}$

\section{Non-Hispanic Black}

$\begin{array}{lccccc}\text { Number of Degrees } & 883 & 935 & 942 & 972 & 945 \\ \text { Percentage of Degrees } & 11 \% & 12 \% & 11 \% & 11 \% & 10 \%\end{array}$

\section{Hispanic}

\begin{tabular}{lccccc} 
Number of Degrees & 966 & 1,166 & 1,437 & 1,433 & 1,645 \\
$\begin{array}{l}\text { Percentage of Degrees } \\
\text { Il-Grant Recipients }\end{array}$ & $12 \%$ & $14 \%$ & $17 \%$ & $16 \%$ & $18 \%$ \\
\hline Number of Degrees & 3,260 & 3,763 & 4,476 & 4,766 & 5,102 \\
Percentage of Degrees & $41 \%$ & $46 \%$ & $50 \%$ & $54 \%$ & $55 \%$
\end{tabular}

Note: Non-Hispanic Black and Hispanic do not include students classified as Non-Resident Alien or students with a missing race code. Students who earn two distinct degrees in the same term are counted twice - whether their degrees are from the same six-digit CIP code or different CIP codes. Students who earn only one degree are counted once - even if they completed multiple majors or tracks. Percentage of Degrees is based on the number of baccalaureate degrees awarded to non-Hispanic Black and Hispanic students divided by the total degrees awarded - excluding those awarded to nonresident aliens and unreported.

Pell-Grant recipients are defined as those students who have received a Pell grant from any SUS Institution within six years of graduation - excluding those awarded to non-resident aliens, who are only eligible for Pell grants in special circumstances. Percentage of Degrees is based on the number of baccalaureate degrees awarded to Pell recipients, as shown above, divided by the total degrees awarded - excluding those awarded to non-resident aliens.

Notes on Trends: In 2007, the US Department of Education re-classified the taxonomy for self-reported race/ethnicity categories and allowed universities a two-year phase-in process before all institutions were required to report based on the new categories for the 2011-12 academic year. This reclassification will impact trends. 


\section{Section 4 - Undergraduate Education (continued)}

\section{TABLE 4J. Baccalaureate Degrees Without Excess Credit Hours}

\begin{tabular}{lccc|cc} 
& $\mathbf{2 0 0 9 - 1 0}$ & $\mathbf{2 0 1 0 - 1 1}$ & $\mathbf{2 0 1 1 - 1 2}$ & $\mathbf{2 0 1 2 - 1 3}$ & $\mathbf{2 0 1 3 - 1 4}$ \\
\hline FTIC & $47 \%$ & $50 \%$ & $57 \%$ & $57 \%$ & $64 \%$ \\
\hline AA Transfers & $58 \%$ & $60 \%$ & $60 \%$ & $70 \%$ & $73 \%$ \\
\hline Other Transfers & $49 \%$ & $49 \%$ & $40 \%$ & $55 \%$ & $60 \%$ \\
\hline TOTAL & $\mathbf{5 1 \%}$ & $\mathbf{5 3} \%$ & $\mathbf{5 3} \%$ & $\mathbf{6 1 \%}$ & $\mathbf{6 6} \%$
\end{tabular}

Notes: This table is based on statute 1009.286 (see link), and excludes certain types of student credits (ie, accelerated mechanisms, remedial coursework, non-native credit hours that are not used toward the degree, non-native credit hours from failed, incomplete, withdrawn, or repeated courses, credit hours from internship programs, credit hours up to 10 foreign language credit hours for transfer students in Florida, and credit hours earned in military science courses that are part of the Reserve Officers' Training Corps (ROTC) program). This metric is not the same as the Excess Hours Surcharge, which has multiple cohorts with varying fee rates. This table reports the percentage of baccalaureate degrees awarded within $110 \%$ of the catalog hours required for a degree based on the Board of Governors Academic Program Inventory. This calculation is based on Hours To Degree data submitted by universities to the Board of Governors and excludes recent graduates who have already earned a baccalaureate degree. Note*: Improvements were made to data collection process beginning with 2012-13 data to better account for high school dual enrolled credits that are exempt from the excess hour calculation. Also, 201213 data marked a slight methodological change in how the data is calculated. Each CIP code's required number of 'catalog hours' was switched to the officially approved hours as reported within the Board of Governors' Academic Program Inventory - instead of the catalog hours reported by the university on the HTD files.

\section{TABLE 4K. Undergraduate Course Offerings}

\begin{tabular}{lccccc} 
& Fall 2009 & Fall 2010 & Fall 2011 & Fall 2012 & Fall 2013 \\
\hline $\begin{array}{c}\text { Number of } \\
\text { Course Sections }\end{array}$ & 3,157 & 3,265 & 3,332 & 3,292 & 3,230 \\
$\begin{array}{l}\text { Percentage of Undergraduate Course Sections by } \\
\text { Class Size }\end{array}$ & & & \\
\hline Fewer than 30 Students & $59 \%$ & $58 \%$ & $61 \%$ & $62 \%$ & $61 \%$ \\
\hline 30 to 49 Students & $28 \%$ & $28 \%$ & $26 \%$ & $25 \%$ & $26 \%$ \\
\hline 50 to 99 Students & $11 \%$ & $11 \%$ & $10 \%$ & $10 \%$ & $9 \%$ \\
\hline 100 or More Students & $3 \%$ & $3 \%$ & $3 \%$ & $3 \%$ & $4 \%$
\end{tabular}

Notes: This data is based on Common Data Set (CDS) definitions. According to CDS, a "class section is an organized course offered for credit, identified by discipline and number, meeting at a stated time or times in a classroom or similar setting, and not a subsection such as a laboratory or discussion session. Undergraduate class sections are defined as any sections in which at least one degree-seeking undergraduate student is enrolled for credit. Exclude distance learning classes and noncredit classes and individual instruction such as dissertation or thesis research, music instruction, or one-to-one readings. Exclude students in independent study, co-operative programs, internships, foreign language taped tutor sessions, practicums, and all students in one-on-one classes. 


\section{Section 4 - Undergraduate Education (continued)}

TABLE 4L. Percentage of Undergraduate Credit Hours Taught by Instructor Type

\begin{tabular}{lccccc} 
& $\mathbf{2 0 0 9 - 1 0}$ & $\mathbf{2 0 1 0 - 1 1}$ & $\mathbf{2 0 1 1 - 1 2}$ & $\mathbf{2 0 1 2 - 1 3}$ & $\mathbf{2 0 1 3 - 1 4}$ \\
\hline Faculty & $65 \%$ & $66 \%$ & $68 \%$ & $66 \%$ & $67 \%$ \\
\hline Adjunct Faculty & $21 \%$ & $19 \%$ & $17 \%$ & $19 \%$ & $18 \%$ \\
\hline Graduate Students & $13 \%$ & $14 \%$ & $15 \%$ & $14 \%$ & $14 \%$ \\
\hline Other Instructors & $1 \%$ & $1 \%$ & $1 \%$ & $1 \%$ & $1 \%$
\end{tabular}

Note: The total number of undergraduate state fundable credit hours taught will be divided by the undergraduate credit hours taught by each instructor type to create a distribution of the percentage taught by each instructor type. Four instructor types are defined as faculty (pay plans 01, 02, and 22), OPS faculty (pay plan 06), graduate student instructors (pay plan 05), and others (all other pay plans). If a course has more than one instructor, then the university's reported allocation of section effort will determine the allocation of the course's total credit hours to each instructor. The definition of faculty varies for Tables 4L, 4M and 4N. For Faculty Teaching Undergraduates, the definition of faculty is based on pay plans 01, 02, and 22.

\section{TABLE 4M. Student/Faculty Ratio}

\begin{tabular}{cccccc} 
& Fall 2009 & Fall 2010 & Fall 2011 & Fall 2012 & Fall 2013 \\
\hline Ratio & 27.3 & 24.0 & 26.1 & 24.0 & 24.0
\end{tabular}

Note: This data is based on Common Data Set (CDS) definitions. This is the Fall ratio of full-time equivalent students (full-time plus $1 / 3$ part time) to fulltime equivalent instructional faculty (full time plus $1 / 3$ part time). The ratio calculations, exclude both faculty and students in stand-alone graduate or professional programs such as medicine, law, veterinary, dentistry, social work, business, or public health in which faculty teach virtually only graduatelevel students. Undergraduate or graduate student teaching assistants are not counted as faculty.

\section{TABLE 4N. Professional Licensure/Certification Exams for Undergraduates}

\begin{tabular}{lccccc} 
Nursing: National Council Licensure Examination for Registered Nurses & & \\
& $\mathbf{2 0 0 9}$ & $\mathbf{2 0 1 0}$ & $\mathbf{2 0 1 1}$ & $\mathbf{2 0 1 2}$ & $\mathbf{2 0 1 3}$ \\
\hline Examinees & 151 & 169 & 210 & 184 & 186 \\
First-time Pass Rate & $96 \%$ & $96 \%$ & $95 \%$ & $93 \%$ & $91 \%$ \\
National Benchmark & $90 \%$ & $89 \%$ & $89 \%$ & $92 \%$ & $85 \%$
\end{tabular}

Note: Pass rate for first-time examinees for the National Council Licensure Examination for Registered Nurses (NCLEX-RN) are based on the performance of graduates of baccalaureate nursing programs. National benchmark data is based on Jan-Dec NCLEX-RN results for first-time examinees from students in US-educated baccalaureate degree programs as published by the National Council of State Boards of Nursing. 


\section{Section 4 - Undergraduate Education (continued)}

TABLE 40. Post-Graduation Metrics

\section{Percent of Bachelor's Graduates Employed Full-time or Continuing their Education, One Year After Graduation}

\begin{tabular}{lccccc} 
& $\mathbf{2 0 0 8 - 0 9}$ & $\mathbf{2 0 0 9 - 1 0}$ & $\mathbf{2 0 1 0 - 1 1 ^ { * }}$ & $\mathbf{2 0 1 1 - 1 2}$ & $\mathbf{2 0 1 2 - 1 3}$ \\
\hline Percent Found Employed or Enrolled & $\mathrm{n} / \mathrm{a}$ & $\mathrm{n} / \mathrm{a}$ & $69 \%$ & $70 \%$ & $75 \%$ \\
Percent Found & $\mathrm{n} / \mathrm{a}$ & $\mathrm{n} / \mathrm{a}$ & $91 \%$ & $89 \%$ & $92 \%$
\end{tabular}

Notes: Percent Found Employed or Enrolled is based on the number of recent baccalaureate graduates who are either employed full-time or continuing their education within one year after graduation. The employed data now includes non-Florida data that is available from the Wage Record Interchange System 2 (known as "WRIS 2") and Federal employee and military data that is available from the Federal Employment Data Exchange System (FEDES) initiative. Full-time employment is based on those who earned more than a full-time (40hrs a week) worker making minimum wage. Due to limitations in the data, the continuing enrollment data includes any enrollment the following year regardless of whether the enrollment was post-baccalaureate or not. Note*: Non-Florida employment data was not available for the 2010-11 graduates.

Percent Found refers to the percentage of graduates found in the dataset - including those that did not earn wages above the full-time threshold and those who were found outside of the one-year window.

For more information about the methodology see: http://www.flbog.edulabout/budget/performance funding.php.

For more information about WRIS2 see: http://www.doleta.gov/performance/wris 2.cfm.

For more information about FEDES see: http://www.ubalt.edu/fififedes/.

Median Wages of Bachelor's Graduates Employed Full-time in Florida, One Year After Graduation

\begin{tabular}{lccccc} 
& $\mathbf{2 0 0 8 - 0 9}$ & $\mathbf{2 0 0 9 - 1 0}$ & $\mathbf{2 0 1 0 - 1 1}$ & $\mathbf{2 0 1 1 - 1 2}$ & $\mathbf{2 0 1 2 - 1 3}$ \\
\hline Median Wage & $\mathrm{n} / \mathrm{a}$ & $\mathrm{n} / \mathrm{a}$ & $\$ 33,200$ & $\$ 34,600$ & $\$ 35,200$ \\
Percent Found & $\mathrm{n} / \mathrm{a}$ & $\mathrm{n} / \mathrm{a}$ & $53 \%$ & $51 \%$ & $53 \%$
\end{tabular}

Notes: Median Wage data is based on Florida's annualized Unemployment Insurance (UI) wage data for those graduates who earned more than a fulltime employee making minimum wage in the fiscal quarter a full year after graduation. This UI wage data does not include individuals who are selfemployed, employed out of state, employed by the military or federal government, or those without a valid social security number. This wage data includes graduates who were both employed and enrolled. Wages rounded to nearest hundreds. Percent Found refers to the percentage of graduates found in the dataset - including those that did not earn wages above the full-time threshold and those who were found outside of the one-year window. 


\section{Section 5 - Graduate Education}

TABLE 5A. Graduate Degree Program Changes in AY 2013-14

\begin{tabular}{|c|c|c|c|c|c|c|}
\hline Title of Program & $\begin{array}{c}\text { Six-digit } \\
\text { CIP } \\
\text { Code }\end{array}$ & $\begin{array}{c}\text { Degree } \\
\text { Level }\end{array}$ & $\begin{array}{l}\text { Date of } \\
\text { UBOT } \\
\text { Action }\end{array}$ & $\begin{array}{l}\text { Starting } \\
\text { or Ending } \\
\text { Term }\end{array}$ & $\begin{array}{c}\text { Date of } \\
\text { Board of } \\
\text { Governors } \\
\text { Action }\end{array}$ & Comments \\
\hline \multicolumn{7}{|l|}{ New Programs } \\
\hline Computer Science & 11.0701 & Masters & Dec. 3, 2013 & 2014 SPRING & & \\
\hline Cybersecurity & 43.0303 & Masters & Oct. 23, 2013 & 2014 FALL & & \\
\hline $\begin{array}{l}\text { Child and Adolescent Behavioral } \\
\text { Health }\end{array}$ & 44.0000 & Masters & Mar. 6, 2014 & 2014 SPRING & & \\
\hline Cell and Molecular Biology & 26.0406 & Research Doctorate & & 2013 FALL & June 20, 2013 & \\
\hline Integrative Biology & 26.1399 & Research Doctorate & & 2013 FALL & June 20, 2013 & \\
\hline Rehabilitation Science & 51.2314 & Research Doctorate & Dec. 5, 2013 & 2013 FALL & June 19, 2014 & \\
\hline \multicolumn{7}{|l|}{ Terminated Programs } \\
\hline Bioethics and Medical Humanities & 51.3201 & Masters & Mar. 6, 2014 & 2014 SUMMER & & \\
\hline Ed of Specific Learning Disabled & 13.1011 & Masters & Mar. 6, 2014 & 2014 SUMMER & & \\
\hline Ed of the Emotionally Handicapped & 13.1005 & Masters & Mar. 6, 2014 & 2014 SUMMER & & \\
\hline Ed of the Mentally Handicapped & 13.1006 & Masters & Mar. 6, 2014 & 2014 SUMMER & & \\
\hline Biology & 26.0101 & Research Doctorate & Mar. 21, 2013 & 2013 FALL & June 20, 2013 & \\
\hline Classics & 16.1200 & Masters & Dec. 5, 2013 & 2014 SUMMER & & \\
\hline \multicolumn{7}{|c|}{ Programs Suspended for New Enrollments } \\
\hline None & & & & & & \\
\hline \multicolumn{7}{|c|}{ New Programs Considered By University But Not Approved } \\
\hline
\end{tabular}

Note: This table does not include new majors or concentrations added under an existing degree program CIP Code. This table reports the new and terminated program changes based on Board action dates between May 5, 2013 and May 4, 2014.

New Programs are proposed new degree programs that have been completely through the approval process at the university and, if appropriate, the Board of Governors. Does not include new majors or concentrations added under an existing degree program CIP Code. Terminated Programs are degree programs for which the entire CIP Code has been terminated and removed from the university's inventory of degree programs. Does not include majors or concentrations terminated under an existing degree program CIP Code if the code is to remain active on the academic degree inventory.

Programs Suspended for New Enrollments are degree programs for which enrollments have been temporarily suspended for the entire CIP Code, but the program CIP Code has not been terminated. Does not include majors or concentrations suspended under an existing degree program CIP Code if the code is to remain active on the academic degree inventory and new enrollments in any active major will be reported. Programs included in this list may have been suspended for new enrollments sometime in the past and have continued to be suspended at least one term of this academic year.

New Programs Considered by University But Not Approved includes any programs considered by the university board of trustees, or any committee of the board, but not approved for implementation. Also include any programs that were returned prior to board consideration by the university administration for additional development, significant revisions, or re-conceptualization; regardless of whether the proposal was eventually taken to the university board for approval. Count the returns once per program, not multiple times the proposal was returned for revisions, unless there is a total re-conceptualization that brings forward a substantially different program in a different CIP Code. 


\section{Section 5 - Graduate Education (continued)}

TABLE 5B. Graduate Degrees Awarded

\begin{tabular}{lrrrrr} 
& $\mathbf{2 0 0 9 - 1 0}$ & $\mathbf{2 0 1 0 - 1 1}$ & $\mathbf{2 0 1 1 - 1 2}$ & $\mathbf{2 0 1 2 - 1 3}$ & $\mathbf{2 0 1 3 - 1 4}$ \\
\hline TOTAL (First Majors) & $\mathbf{2 , 9 4 4}$ & $\mathbf{3 , 0 1 0}$ & $\mathbf{3 , 1 5 9}$ & $\mathbf{3 , 2 0 9}$ & $\mathbf{3 , 4 0 1}$ \\
\hline TOTAL (Second majors) & $\mathbf{0}$ & $\mathbf{0}$ & $\mathbf{0}$ & $\mathbf{0}$ & $\mathbf{0}$ \\
\hline Masters and Specialist (first majors) & 2,544 & 2,585 & 2,742 & 2,761 & 2,855 \\
Research Doctoral (first majors) & 244 & 269 & 271 & 295 & 330 \\
Professional Doctoral (first majors) & 156 & 156 & 146 & 153 & 216 \\
\hline Dentistry & 0 & 0 & 0 & 0 & 0 \\
Law & 0 & 0 & 0 & 0 & 0 \\
Medicine & 116 & 109 & 112 & 106 & 120 \\
Nursing Practice & 10 & 12 & 6 & 5 & 6 \\
Pharmacy & 0 & 0 & 0 & 0 & 0 \\
Physical Therapist & 30 & 35 & 28 & 42 & 90 \\
\hline Veterinary Medicine & 0 & 0 & 0 & 0 & 0 \\
Other & 0 & 0 & 0 & 0 & 0
\end{tabular}

Note: This table reports the total number of graduate level degrees that were awarded by academic year as well as the number by level. The table provides a breakout for the Professional Doctoral degrees. USF and BOG data have slight differences in the number of degrees awarded - the data presented above are from the State University Database System (SUDS).

\section{TABLE 5C. Graduate Degrees Awarded in Areas of Strategic Emphasis}

[Includes Second Majors]

\begin{tabular}{lccccc} 
& $\mathbf{2 0 0 9 - 1 0}$ & $\mathbf{2 0 1 0 - 1 1}$ & $\mathbf{2 0 1 1 - 1 2}$ & $\mathbf{2 0 1 2 - 1 3}$ & $\mathbf{2 0 1 3 - 1 4}$ \\
\hline STEM & 616 & 658 & 730 & 845 & 932 \\
\hline HEALTH & 624 & 747 & 729 & 762 & 838 \\
\hline GLOBALIZATION & 27 & 27 & 31 & 29 & 25 \\
\hline EDUCATION & 506 & 551 & 572 & 493 & 453 \\
\hline GAP ANALYSIS & 62 & 55 & 66 & 90 & 97 \\
\hline SUBTOTAL & 1,835 & 2,038 & 2,128 & 2,219 & 2,345 \\
\hline PSE PERCENT OF TOTAL & $62 \%$ & $\mathbf{6 8 \%}$ & $\mathbf{6 7 \%}$ & $\mathbf{6 9 \%}$ & $\mathbf{6 9 \%}$
\end{tabular}

Notes: This is a count of graduate degrees awarded within specific Programs of Strategic Emphasis, as determined by the Board of Governors staff with consultation with business and industry groups and input from universities - for more information see:

http://www.flbog.edu/pressroom/strategic emphasis/. The Board of Governors revised the list of Programs of Strategic Emphasis in November 2013, and the new categories were applied to the historical degrees. A student who has multiple majors in the subset of targeted Classification of Instruction Program codes will be counted twice (i.e., double-majors are included). Note: The denominator used in the percentage includes second majors. 
Section 5 - Graduate Education (continued)

TABLE 5D. Professional Licensure Exams for Graduate Programs

Medicine: US Medical Licensing Exam - Step 1 (for 2nd year MD students)

\begin{tabular}{lccccc} 
& $\mathbf{2 0 1 0}$ & $\mathbf{2 0 1 1}$ & $\mathbf{2 0 1 2}$ & $\mathbf{2 0 1 3}$ & $\mathbf{2 0 1 4}$ \\
\hline Examinees & 116 & 110 & 125 & 145 & 147 \\
First-time Pass Rate & $97 \%$ & $99 \%$ & $91 \%$ & $96 \%$ & $95 \%$ \\
National Benchmark & $91 \%$ & $94 \%$ & $96 \%$ & $96 \%$ & $96 \%$
\end{tabular}

Medicine: US Medical Licensing Exam - Step 2 Clinical Knowledge (for $4^{\text {th }}$ year MD students)

\begin{tabular}{lccccc} 
& $\mathbf{2 0 0 9 - 1 0}$ & $\mathbf{2 0 1 0 - 1 1}$ & $\mathbf{2 0 1 1 - 1 2}$ & $\mathbf{2 0 1 2 - 1 3}$ & $\mathbf{2 0 1 3 - 1 4}$ \\
\hline Examinees & 128 & 122 & 115 & 152 & 136 \\
First-time Pass Rate & $100 \%$ & $99 \%$ & $99 \%$ & $100 \%$ & $98 \%$ \\
National Benchmark & $97 \%$ & $97 \%$ & $98 \%$ & $98 \%$ & $97 \%$
\end{tabular}

Medicine: US Medical Licensing Exam - Step 2 Clinical Skills (for $4^{\text {th }}$ year MD students)

\begin{tabular}{lccccc} 
& $\mathbf{2 0 0 9 - 1 0}$ & $\mathbf{2 0 1 0 - 1 1}$ & $\mathbf{2 0 1 1 - 1 2}$ & $\mathbf{2 0 1 2 - 1 3}$ & $\mathbf{2 0 1 3 - 1 4}$ \\
\hline Examinees & 116 & 122 & 100 & 128 & 142 \\
First-time Pass Rate & $96 \%$ & $100 \%$ & $98 \%$ & $99 \%$ & $91 \%$ \\
National Benchmark & $97 \%$ & $98 \%$ & $97 \%$ & $98 \%$ & $96 \%$
\end{tabular}

Physical Therapy: National Physical Therapy Examinations

\begin{tabular}{lccccc} 
& $\mathbf{2 0 0 7 - 0 9}$ & $\mathbf{2 0 0 8 - 1 0}$ & $\mathbf{2 0 0 9 - 1 1}$ & $\mathbf{2 0 1 0 - 1 2}$ & $\mathbf{2 0 1 1 - 1 3}$ \\
\hline Examinees & 51 & 81 & 96 & 93 & 92 \\
First-time Pass Rate & $86 \%$ & $85 \%$ & $87 \%$ & $90 \%$ & $94 \%$ \\
National Benchmark & $87 \%$ & $87 \%$ & $89 \%$ & $89 \%$ & $89 \%$
\end{tabular}

Note: Due to the low number of examinees, this table reports a three-year average pass rate for first-time examinees on the National Physical Therapy Examinations by exam year. 


\section{Section 6 - Research and Economic Development}

TABLE 6A. Research and Development

$\begin{array}{lllll}2008-09 & 2009-10 & 2010-11 & 2011-12 & 2012-13\end{array}$

\section{R\&D Expenditures}

Total (S\&E and non-S\&E)

(\$1,000s)

$\$ 371,037$

$\$ 390,828$

$\$ 400,679$

$\$ 451,259$

$\$ 467,355$

Federally Funded

(\$1,000s)

$\$ 213,163 \quad \$ 246,016 \quad \$ 245,410 \quad \$ 239,902 \quad \$ 228,460$

Percent Funded

From External Sources

$70 \%$

$70 \%$

$70 \%$

$62 \%$

$59 \%$

Total R\&D Expenditures

Per Full-Time, Tenured,

Tenure-Earning Faculty Member (\$)

$\$ 339,467 \quad \$ 356,595 \quad \$ 360,323 \quad \$ 395,148$

$\$ 421,801$

\section{Technology Transfer}

\begin{tabular}{|c|c|c|c|c|c|}
\hline Invention Disclosures & 141 & 161 & 172 & 177 & 185 \\
\hline U.S. Patents Issued & 36 & 66 & 91 & 98 & 76 \\
\hline $\begin{array}{l}\text { Patents Issued Per 1,000 } \\
\text { Full-Time, Tenured and Tenure- } \\
\text { Earning Faculty }\end{array}$ & 33 & 60 & 82 & 86 & 69 \\
\hline Licenses/ Options Executed & 25 & 37 & 36 & 52 & 75 \\
\hline $\begin{array}{l}\text { Licensing Income } \\
\text { Received (\$) }\end{array}$ & $\$ 1,300,000$ & $\$ 17,411,625$ & $\$ 1,390,871$ & $\$ 1,243,425$ & $\$ 1,802,233$ \\
\hline Number of Start-Up Companies & 3 & 5 & 8 & 10 & 9 \\
\hline
\end{tabular}

Note: R\&D Expenditures are based on the National Science Foundation's annual Survey of R\&D Expenditures at Universities and Colleges (data include Science \& Engineering and non-Science \& Engineering awards). Percent Funded from External Sources is defined as funds from federal, private industry and other sources (non-state and non-institutional funds). Total R\&D expenditures are divided by fall, full-time tenured/tenure-track faculty as reported to IPEDS (FGCU includes both tenured/tenure-track and non-tenure/track faculty). The fall faculty year used will align with the beginning of the fiscal year, so that (e.g.) 2007 FY R\&D expenditures are divided by fall 2006 faculty. Technology Transfer data are based on the Association of University Technology Managers Annual Licensing Survey. Licensing Income Received refers to license issue fees, payments under options, annual minimums, running royalties, termination payments, amount of equity received when cashed-in, and software and biological material end-user license fees of $\$ 1,000$ or more, but not research funding, patent expense reimbursement, valuation of equity not cashed-in, software and biological material end-user license fees of less than $\$ 1,000$, or trademark licensing royalties from university insignia. Number of Start-up Companies that were dependent upon the licensing of University technology for initiation. 


\section{Section 6 - Research and Economic Development (continued)}

\section{TABLE 6B. Centers of Excellence}

\begin{tabular}{|c|c|c|c|}
\hline Name of Center: & Center for Drug Discovery and Innovation (CDDI) & \multirow{2}{*}{$\begin{array}{l}\text { Cumulative } \\
\text { (since inception } \\
\text { to June 2014) }\end{array}$} & \multirow{2}{*}{$\begin{array}{l}\text { Fiscal Year } \\
\text { 2013-14 }\end{array}$} \\
\hline Year Created: & 2007 & & \\
\hline \multicolumn{4}{|c|}{$\begin{array}{l}\text { Research Effectiveness } \\
\text { Only includes data for activities directly associated with the Center. Does not include the non-Center activities for faculty who are } \\
\text { associated with the Center. }\end{array}$} \\
\hline \multicolumn{2}{|c|}{ Number of Competitive Grants Applied For } & 194 & 34 \\
\hline \multicolumn{2}{|c|}{ Value of Competitive Grants Applied For (\$) } & $\$ 133,194,149$ & $\$ 22,074,285$ \\
\hline \multicolumn{2}{|c|}{ Number of Competitive Grants Received } & 68 & 11 \\
\hline \multicolumn{2}{|c|}{ Value of Competitive Grants Received (\$) } & $\$ 37,956,326$ & $\$ 9,527,785$ \\
\hline \multicolumn{2}{|c|}{ Total Research Expenditures (\$) } & $\$ 19,607,857$ & $\$ 1,451,754$ \\
\hline \multicolumn{2}{|c|}{$\begin{array}{l}\text { Number of Publications in Refereed Journals } \\
\text { From Center Research }\end{array}$} & 193 & 21 \\
\hline \multicolumn{2}{|c|}{ Number of Invention Disclosures } & 50 & 8 \\
\hline \multicolumn{2}{|c|}{ Number of Licenses/Options Executed } & 7 & 4 \\
\hline \multicolumn{2}{|c|}{ Licensing Income Received (\$) } & $\$ 164,071$ & $\$ 1,000$ \\
\hline \multicolumn{4}{|c|}{$\begin{array}{l}\text { Collaboration Effectiveness } \\
\text { Only reports on relationships that include financial or in-kind support. }\end{array}$} \\
\hline \multicolumn{2}{|c|}{ Collaborations with Other Postsecondary Institutions } & 68 & 6 \\
\hline \multicolumn{2}{|c|}{ Collaborations with Private Industry } & 103 & 9 \\
\hline \multicolumn{2}{|c|}{ Collaborations with K-12 Education Systems/Schools } & 48 & 0 \\
\hline \multicolumn{2}{|c|}{$\begin{array}{l}\text { Undergraduate and Graduate Students Supported } \\
\text { with Center Funds }\end{array}$} & 84 & 17 \\
\hline \multicolumn{4}{|c|}{ Economic Development Effectiveness } \\
\hline \multicolumn{2}{|c|}{$\begin{array}{l}\text { Number of Start-Up companies } \\
\text { with a physical presence, or employees, in Florida }\end{array}$} & 1 & 1 \\
\hline \multicolumn{2}{|c|}{$\begin{array}{l}\text { Jobs Created By Start-Up Companies } \\
\text { Associated with the Center }\end{array}$} & 5 & 2 \\
\hline \multicolumn{2}{|c|}{ Specialized Industry Training and Education } & 14 & 0 \\
\hline \multicolumn{2}{|c|}{$\begin{array}{l}\text { Private-sector Resources Used to Support } \\
\text { the Center's Operations }\end{array}$} & 0 & 0 \\
\hline
\end{tabular}




\section{Section 6 - Research and Economic Development (continued) \\ TABLE 6B. Centers of Excellence (continued)}

\section{Name of Center}

Center for Drug Discovery and Innovation (CDDI)

Narrative Comments [Most Recent Year]:

(1) On December 1, 2013, Dr. Michael White was awarded an NIH 5 year R01 grant totaling $\$ 2,123,111$ to further research on malaria related diseases. Other CDDI faculty members that are collaborators on this grant includes Assistant Research Professor, Dr. Elena Suvorova and Medicinal Chemist, Dr. James Leahy.

(2) Dr. Bill Baker, Director, CDDI, was awarded a \$1.7 million grant from NSF to further research on marine ecology in Antarctica. This four grant will support the collaborative efforts between the University of South Florida and the University of Alabama at Birmingham.

(3) CDDI recently acquired the latest in benchtop liquid chromatography-mass spectrometry (LC-MS)system for high-throughput screening for its Proteomics Lab. Funds for the purchasing of this new equipment, which cost $\$ 500,000$, were secured through a collaborative effort between USF Research \& Innovation, College of Medicine, College of Arts \& Science, Public Health, Global Health and the Center for Drug Discovery and Innovation. 